OPEN ACCESS

Edited by: Ursula Grohmann, University of Perugia, Italy

Reviewed by: Maurizio Muraca, University of Padua, Italy Santiago Roura, Germans Trias i Pujol Health Science Research Institute (IGTP), Spain

${ }^{*}$ Correspondence: Barbara Lukomska barbara.lukomska@imdik.pan.p

Specialty section: This article was submitted to Immunological Tolerance and Regulation, a section of the journal

Frontiers in Immunology

Received: 27 August 2020 Accepted: 21 December 2020 Published: 05 February 2021

Citation:

Dabrowska S, Andrzejewska A Janowski M and Lukomska B (2021) Immunomodulatory and Regenerative

Effects of Mesenchymal Stem Cells and Extracellular Vesicles: Therapeutic

Outlook for Inflammatory and

Degenerative Diseases.

Front. Immunol. 11:591065. doi: 10.3389/fimmu.2020.591065

\section{Immunomodulatory and Regenerative Effects of Mesenchymal Stem Cells and Extracellular Vesicles: Therapeutic Outlook for Inflammatory and Degenerative Diseases}

\author{
Sylwia Dabrowska ${ }^{1}$, Anna Andrzejewska ${ }^{1}$, Miroslaw Janowski ${ }^{1,2,3}$ \\ and Barbara Lukomska ${ }^{1 *}$ \\ ${ }^{1}$ NeuroRepair Department, Mossakowski Medical Research Centre, PAS, Warsaw, Poland, ${ }^{2}$ University of Maryland School \\ of Medicine, Baltimore, MD, United States, ${ }^{3}$ Center for Advanced Imaging Research, Department of Diagnostic Radiology \\ and Nuclear Medicine, University of Maryland School of Medicine, Baltimore, MD, United States
}

Mesenchymal stem cells (MSCs) are non-hematopoietic, multipotent stem cells derived from mesoderm, which can be easily isolated from many sources such as bone marrow, umbilical cord or adipose tissue. MSCs provide support for hematopoietic stem cells and have an ability to differentiate into multiple cell lines. Moreover, they have proangiogenic, protective and immunomodulatory properties. MSCs have the capacity to modulate both innate and adaptive immune responses, which accompany many diseases, by inhibiting pro-inflammatory reactions and stimulating anti-inflammatory activity. Recent findings revealed that the positive effect of MSCs is at least partly associated with the production of extracellular vesicles (EVs). EVs are small membrane structures, containing proteins, lipids and nuclei acids, which take part in intra-cellular communication. Many studies indicate that EVs contain protective and pro-regenerative properties and can modulate an immune response that is activated in various diseases such as CNS diseases, myocardial infarction, liver injury, lung diseases, ulcerative colitis or kidney injury. Thus, EVs have similar functions as their cells of origin and since they do not carry the risk of cell transplantation, such as tumor formation or small vessel blockage, they can be considered a potential therapeutic tool for cell-free therapy.

Keywords: extracellular vesicles, mesenchymal stem cells, immunomodulation, protection, regeneration 


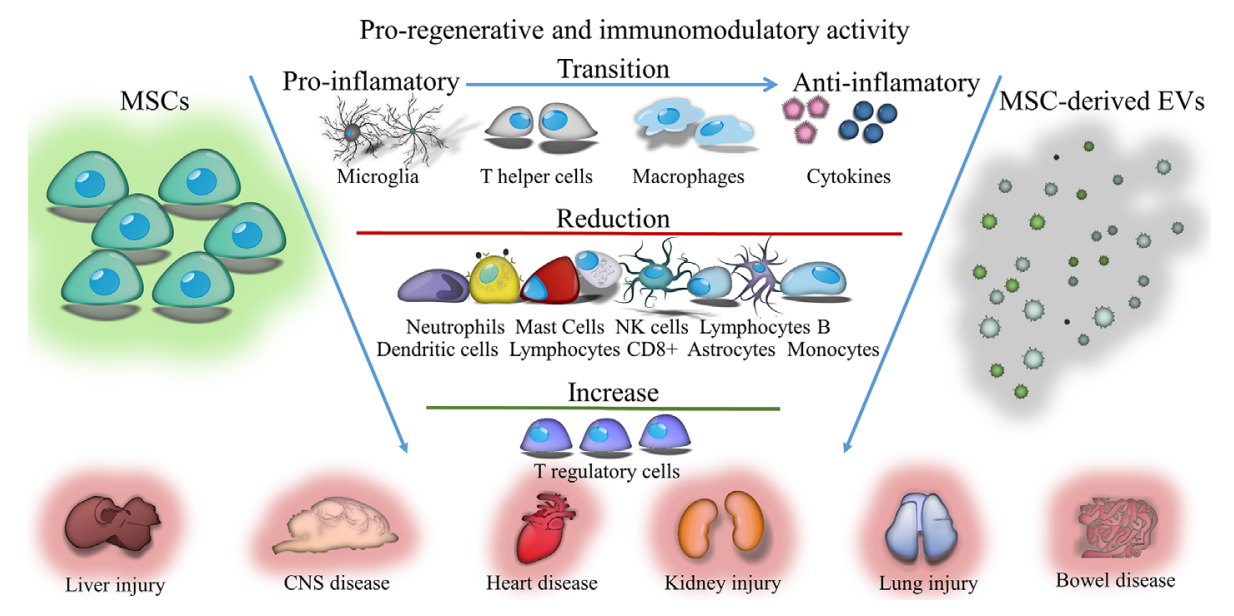

GRAPHICAL ABSTRACT | Immunomodulatory and regenerative effects of mesenchymal stem cells (MSCs) or extracellular vesicles (EVs) derived from them in inflammatory and degenerative diseases.

\section{INTRODUCTION}

Immunomodulation is increasingly being considered as a therapeutic alternative for an array of incurable diseases. It frequently is achieved by blocking harmful effects of the immune response while also promoting beneficial interactions of the immune system with disordered tissues. There is growing evidence that mesenchymal stem cell (MSC) transplantation has a positive effect by stimulating repair processes after injury and modulating the recipient's immune response. This cross-talk between donor MSCs and recipient cells seems extremely important for normalization of homeostasis of the body and for survival and preservation of functions after cell damage. Hence, the development of "immunomodulatory strategies," used to control the functions of individual immune cell populations at various stages of disease, seems to be a promising therapeutic approach. The transplantation of MSCs, which has strong immunomodulatory properties, may be one of them. Due to the strong paracrine properties, transplanted MSCs release a number of trophic factors into the host environment that are involved in reducing inflammation, apoptosis and

\footnotetext{
Abbreviations: BDNF, brain-derived neurotrophic factor; bFGF, basic fibroblast growth factor; CKD, chronic kidney disease; COVID-19, coronavirus disease 2019; COX-2, cyclooxygenase-2; DCs, dendritic cells; EGF, epidermal growth factor; EV(s), extracellular vesicle(s); FGF, fibroblast growth factor; GDNF, gliogenic neurotrophic factor; GM-CSF, granulocyte and macrophage colony-stimulating factor; G-CSF, granulocyte colony stimulating factor; GVHD, graft-versus-host disease; hBM-MSCs, human bone marrow stem cells; HGF, hepatocyte growth factor; IDO, indolamine 2,3dioxygenase; IGF-1, insulin-like growth factor; IFN- $\gamma$, interferon- $\gamma$; LIF, leukemia inhibitory factor; $\mathrm{MHC}$, major histocompatibility complex; MI/R, myocardial/ reperfusion; miRNA, microRNA; mRNA, messenger RNA; MSC-EVs, EVs derived from MSCs; MSC(s), mesenchymal stem cell(s); NGF $\beta$, beta nerve growth factor; NK, natural killer; PDGF, platelet-derived growth factor; PGE-2, prostaglandin E-2; SARS$\mathrm{CoV}-2$, severe acute respiratory syndrome coronavirus 2 ; SCF, stem cell growth factor; SDF-1, stromal-derived factor 1; TBI, traumatic brain injury; TGF $\beta$, transforming growth factor $\beta$; Th, T helper; Treg, T regulatory; VEGF, vascular endothelial growth factor.
}

fibrosis of damaged tissues. Studies conducted in recent years have shown that the therapeutic effects of MSCs can be also conveyed through extracellular vesicles (EVs). It seems that EVs released from MSCs may perform the same functions as the cells from which they originate. Previous studies revealed that the content of EVs transferred to surrounding cells can change their fate and properties. Being natural carriers of bioactive substances, EVs administered under ischemic conditions can reprogram endogenous cells in damaged tissue, modulating their functions and immunosuppressive activity, and limiting the proinflammatory response. Therefore, verification of extracellular vesicle effects in preclinical studies compared to MSC transplantation is justified.

\section{MSCs: Discovery and Sources}

MSCs are non-hematopoietic, multipotent stem cells, as evident by their name, which is derived from the middle germ layer mesoderm. They were first found in the bone marrow by Friedenstein in the late 1960s and described as fibroblast-like cells, adherent to plastic, forming clones, with the ability to selfrenew in vitro and differentiate into osteoblasts, chondrocytes and adipocytes (1). For many years, MSCs have been called bone marrow stromal stem cells $(2,3)$. The name "mesenchymal stem cells" was first introduced by Caplan in 1991 (4). Many researchers refer to MSCs as "mesenchymal stromal cells" because of their origin. In 2017, Caplan suggested that the name of MSCs should be changed to "medicinal signaling cells" to emphasize the fact that MSCs migrate to the site of damage or pathology due to disease-related secretion of biologically active regenerative and immunomodulatory factors (5). Bone marrow is one of the most widely used sources of MSCs, in which they constitute $0.001 \%$ to $0.01 \%$ of mononuclear cells (6-8). MSCs also can be isolated from other sources. Isolation procedure for MSCs from various tissues from adult donors is not very invasive and does not raise ethical and legal 
objections. Many researchers obtain MSCs from tissues discarded at delivery such as umbilical cord blood $(9,10)$, Wharton's jelly umbilical cord $(11,12)$, placenta $(13,14)$ and amniotic fluid (15). In recent years, more and more research has been conducted using MSCs isolated from adipose tissue (16, 17). In addition, it is possible to obtain MSCs from other sources, such as skin (18), lungs (19), liver (20) dental pulp (21), endometrium (22), fallopian tube (23), and anterior or posterior cruciate knee ligaments (24).

\section{Characterization of MSCs}

In accordance with the recommendations of the Mesenchymal Stem Cells and Tissue Stem Cells Committee of the International Society for Cell Therapy, in addition to the proliferative and selfrenewing characteristics of all stem cells, human MSCs must meet the following criteria: ability to adhere to and grow on plastic under standard laboratory conditions; presence of markers typical for MSCs: CD105, CD73, CD90, in at least 95\% of cells and no markers of hematopoietic cells: CD45, CD34, CD14 or CD11b, CD79 $\alpha$, CD19, human leukocyte antigens class II, measured by flow cytometry; ability to differentiate into three types of cells: osteoblasts, adipocytes and chondroblasts under standard in vitro conditions. These criteria are typical of human MSCs. MSCs isolated from other animal species must be able to adhere to the surface of plastic and to differentiate into three cell types, but may differ in expression of surface antigen (25).

MSCs grown in culture on a plastic surface have an elongated, fusiform shape, and their morphology resembles fibroblasts. Initially, the MSC population was thought to be more than $98 \%$ homogeneous and consist of identical, symmetrical, spindle cells (8). However, later studies have shown that MSC colonies are heterogeneous and consist of smaller spindle cells capable of faster self-renewal and larger cubic-shaped cells or flattened, slower proliferating cells. The Colter group presented a third type of cells, described as very small cells capable of rapid self-renewal, showing the greatest potential for differentiation and considered early cell progenitors (26). In in vitro culture, MSCs seeded on a plastic surface reach confluence after 5 to 7 days. After covering the entire area of the flask they begin to grow in several layers, change their shape, flatten and their numerous branches become visible (27). MSCs are capable of 25 to 40 doubling the population, which is 8 to 15 passages, while retaining the ability to differentiate (28). Under laboratory conditions, MSCs grow in three phases: the lag phase lasting 3 to 4 days, the log phase and the stationary phase (26). Studies have shown that phase change is associated with different expression of genes, including Dickkopf genes, whose highest levels are observed in the phase of rapid growth and Wnt5a genes, which are expressed at the highest level in the stationary phase (29). In addition, MSC cell cycle analysis showed that the majority, as much as $89 \%$ of the cells, are in the G0/G1 phase, $6 \%$ in phase $\mathrm{G}(2) / \mathrm{M}$ and $5 \%$ in phase $S$ of the cell cycle. These cells retain a normal karyotype (11). In vivo, MSCs occupy special places in various body tissues called stem cell niches. The specific microenvironment prevailing in niches and interactions with other cells cause MSCs to remain in dormant and are activated only under the influence of a damaging, pathogenic or aging factor. The hypothesis of the existence of a niche of stem cells in the bone marrow was proposed by Schofield in the 1970s (30). The Wnt signaling pathway is probably involved in the mechanism that allows cells to remain dormant or begin the differentiation process (31).

In addition to markers used in the classification of MSCs, such as CD105 (SH2), CD73 (SH3 and SH4) and CD90 (Thy-1), MSCs derived from bone marrow show the presence of other antigens, including: CD10, CD13, CD146, CD271, CD44, Stro-1, stage-specific embryonic antigen-4, neurotic ganglioside, 3G5, stage-specific embryonic antigen 3, stem cell antigen 1, Stro-4, mesenchymal stromal cell antigen-1, PODXL, Sox1, and TM4SF1 (32). MSCs do not have proteins typical of hematopoietic and endothelial cells: CD11b, CD14, CD31, CD33, CD34, CD133, and CD45 (8). In addition, MSCs possess messenger RNA (mRNA) for cell adhesion molecules such as CD106 (vascular cell adhesion protein 1), CD166 (a molecule activating cell leukocyte adhesion), CD29 (beta 1 integrin), CD49a, b, c, e, f (integrin alpha 1, 2, 3, 4, and 6), integrin alpha 11, CD51 (alpha V integrin), CD54 (intercellular adhesion molecule 1), E-cadherin, CD56 (neuron adhesion molecules) (33). Studies have shown that on the surface of MSCs derived from bone marrow, receptors for chemokines from the CC group are present, including CCR1, CCR3, CCR7, CCR9, CCR10, and from the CXC group, including such as CXCR3, CXCR4, CXCR5, and CXCR6 $(33,34)$.

An important feature of MSCs is their low immunogenicity. They show low expression of major histocompatibility complex (MHC) class I proteins, and they do not express co-stimulatory molecules. Many in vitro studies have shown that MSCs do not induce an immune response from allogeneic lymphocytes (35). In vivo experiments confirmed that MSCs do not induce a typical immune response after allogeneic transplantation, which makes it possible to use MSCs from other donors in clinical therapies (36). However, other researchers indicated that MSCs under specific environmental conditions may induce immune responses. Khan and colleagues have shown that MSCs exhibit the function of antigen presenting cells and activate $\mathrm{T}$ lymphocytes under the influence of interferon- $\gamma$ (IFN- $\gamma$ ) (37). Eliopoulos et al. observed that subcutaneous allogeneic MSCs were rejected in unimmunized mice, accompanied by an increase in IFN- $\boldsymbol{\gamma}$ (38). However, despite the negative results of some research groups, most studies have confirmed the low immunogenicity of MSCs and their survival in the recipient after allogeneic and even xenogeneic transplantation.

\section{Properties and Mechanism of Action of MSCs}

Growth factors, chemokines and cytokines, secreted by damaged cells have the ability to stimulate and mobilize MSCs. Under the influence of mediators such as vascular endothelial growth factor (VEGF), stromal-derived factor 1 (SDF-1), granulocyte colony stimulating factor (G-CSF), granulocyte and macrophage colony-stimulating factor (GM-CSF), erythropoietin, angiopoietin 2, placental growth factor, platelet-derived growth 
factor (PDGF), stem cell growth factor (SCF), insulin-like growth factor (IGF-1), epidermal growth factor (EGF), hepatocyte growth factor (HGF), and cytokines, including IL-1 $1 \beta$, IL-2, IL3, IL-6, IL-8, and tumor necrosis factor $\alpha$ (TNF- $\alpha$ ) and chemokines, including CCL5 and CCL22, MSCs are activated, migrate, and settle in the appropriate tissues $(39,40)$. Proteins present on the surface of MSCs, such as receptors for CC and CXC chemokines, beta 1 and alpha 4 integrins, and vascular cell adhesion protein 1 and intercellular adhesion molecule 1 integrin ligands are involved in the movement and colonization of MSCs (41). After colonization of the target site in the tissue, MSCs proliferate and differentiate into different cell types. These processes are regulated by the interactions of the Wnt, Notch protein signaling pathways and Hedgehog (31). MSCs can multiply and then transform into specialized cells that make up the tissue and replace dying cells. MSCs have been shown to have the ability to differentiate not only into mesodermal cells: osteoblasts, chondrocytes, adipocytes (8) and myocytes $(42,43)$, but in endodermal line cells: hepatocytes $(44,45)$, islet cells $(46)$ or the ectodermal line: neurons (47). In addition, MSCs can associate with other types of cells via cell fusion, thus "saving" damaged or dying cells (48).

The action of MSCs can be associated not only with a direct mechanism, through their differentiation and replacement of damaged cells, but primarily with their paracrine properties. MSCs produce a number of substances, such as cytokines, chemokines and growth factors that can protect and regenerate other cells, as well as stimulate their proliferation and differentiation. The most important secreted growth factors include: transforming growth factor $\beta$ (TGF $\beta$ ), VEGF, IGF-1, SDF, GM-CSF, G-CSF, HGF, EGF, fibroblast growth factor (FGF), beta nerve growth factor (NGF $\beta$ ), macrophage colonystimulating factor, and leukemia inhibitory factor (LIF). In addition, MSCs produce a number of cytokines, including IL $1 \alpha$, IL-1 $\beta$, IL-2, IL-6, IL-7, IL-8, IL-10, IL-11, IL-12, IL-14, IL-15, TNF $\alpha$, and chemokines: CXCL12 (SDF-1), CCL2, CCL5, which are responsible for many functions of MSCs, primarily for their immunomodulatory activity (46-52). They produce extracellular matrix proteins, such as fibronectin, laminin, collagen, and proteoglycans (27).

MSCs can transfer to other cells using tunneling nanotubes not only numerous molecules such as proteins and nucleic acids but also even whole organelles, mainly mitochondria. The Prockop group was the first to indicate that human MSCs co-cultured with a line of lung epithelial cells, devoid of mitochondria, protect cell damage by transferring mitochondria and mitochondrial DNA (53). The transfer of mitochondria through MSCs via tunneling nanotubes to other types of cells, such as endothelial cells or cardiomyocytes, has also been described by others (48).

\section{Biological Functions of MSCs}

One of the earliest known functions of MSCs is to provide an adequate microenvironment for hematopoietic stem cells in the bone marrow. MSCs are a mechanical support for hematopoietic cells due to the production of numerous extracellular matrix proteins such as fibronectin, laminin, collagen and proteoglycans (54). In addition, thanks to secreted cytokines, chemokines and growth factors, MSCs regulate hematopoiesis. In vitro studies using cell co-culture have shown that MSCs produce growth factors, such as SCF and GM-CSF and interleukins, including IL6 , IL-7, and IL-11, activating hematopoietic cells to proliferate and differentiate towards lymphocytes, monocytes, basophils, eosinophils, erythrocytes, as well as megakaryocytes (55). CXCL12 chemokine produced by mesenchymal cells has been proven to play a key role in growth and maintaining hematopoietic stem cells in bone marrow stem cell niches (56). Studies by Muguruma et al. have shown that MSCs transplanted into mice can differentiate into pericytes, myofibroblasts, stromal cells, osteocytes and endothelial cells, and promote the increase of functionally and phenotypically of immature hematopoietic cells (57).

Participation in the process of angiogenesis is another important task of MSCs. MSCs produce numerous growth factors, cytokines and chemokines that induce endothelial cell proliferation, migration and survival, and activate blood vessel formation and maturation (58). Studies of Kinnaird and Hung groups proved that MSCs activate the proliferation and migration of endothelial cells by secreting the proangiogenic factors VEGF and FGF by inducing angiogenesis $(59,60)$. The results of the experiments of $\mathrm{Wu}$ et al. showed that transplanted mesenchymal bone marrow cells are involved in wound healing through the release of VEGF and angiopoietin 1 (61).

Another function of MSCs is their neuroprotective effect on damaged or dying nerve cells, through the production of various growth factors and cytokines. Studies carried out by many authors have proven that mediators secreted by MSCs, such as brain-derived neurotrophic factor (BDNF), gliogenic neurotrophic factor (GDNF), neurotrophin-3, NGF, and VEGF, have neuroprotective effects on nerve cells, causing them to survive and activate growth (62). Johnson et al. demonstrated that the protective effect of MSCs on nerve cells is associated with the production of 11 factors: BDNF, IFN- $\gamma$, IL6, IL-11, LIF, NGF, PDGF-AA, PDGFAB/BB, SCF, melatons, and thrombospondin 1 (63). In addition, MSCs through the release of factors, including those such as TGF- $\beta$, VEGF, or IL-6, act neuroprotectively on scraps of nerve tissue damaged by oxygen and glucose deprivation (49).

Mesenchymal cells show protective properties not only against neuronal cells but also against other types of cells. Studies by Preda et al. have shown that transplanted MSCs perform cardioprotective functions, protecting myocardial cells against ischemia-reperfusion injury (64). Other experiments indicated that MSCs have protective effects on cells in a model of acute ischemia-induced kidney damage due to paracrine activity (65). Experiments using co-culture of pancreatic islets with mesenchymal cells derived from rat bone marrow proved that cytoprotective and anti-apoptotic properties of MSCs are associated with IL- 6 and TGF- $\beta$ secretion and expression of antiapoptotic genes, such as Mapkapk2, Tnip1 and Bcl3 (66).

As a result of their ability to self-renew and differentiate into different cell lines, MSCs perform regenerative functions by replacing dying cells in various tissues. According to standard protocols, MSCs in vitro under the influence of dexamethasone, glycerophosphate and ascorbic acid differentiate into osteoblasts 
showing the presence of mineral aggregates and increased alkaline phosphatase activity. Research by Pittenger and other authors has shown that factors such as bone morphogenetic proteins and growth factors such as TGF, IGF-1, BDNF, and FGF-2 are involved in the osteogenesis process $(8,27)$. In turn, under the influence of the medium used for culture enriched with insulin-transferrin-selenium, linoleic acid, selenic acid, pyruvate, ascorbate 2-phosphate, dexamethasone and TGF- $\beta$, MSCs cells differentiate into collagen-containing chondrocytes $(8,67)$. MSCs which grow in the medium with the addition of dexamethasone, indomethacin, isobutyl, methyl and insulin may differentiate into adipocytes, and after three weeks exhibit the presence of fat drops and the expression of genes specific for these cells, including receptors activated by $\gamma$-peroxisome proliferators, adipocyte proteins 2 and lipoprotein lipase $(8,68)$.

Additionally, studies conducted by $\mathrm{Xu}$ et al. have shown that MSCs derived from rat bone marrow can differentiate under the influence of 5-azacytidine into cardiomyocytes, expressing genes specific for myocardial cells, including myosin $\beta$ heavy chain, $\alpha$ cardiac actin and desmin (43). The experiments of Alimperti et al. have shown that MSCs exposed to cadherin-11 and TGF- $\beta 1$ transform into functionally active smooth muscle cells (42). Under specific in vitro culture conditions, mature hepatocytes may be generated from human bone marrow stem cells (hBMMSCs). In the first stage, the cells differentiate under the influence of EGF-enriched medium, basic fibroblast growth factor (bFGF) and nicotinamide, and then ripen with oncostatin $\mathrm{M}$, dexamethasone and insulin-transferrin-selenium $(44,45)$. Studies performed by Bai et al. have shown the possibility of differentiation of MSCs into pancreatic islet cells, expressing Pdx1, insulin, and C-peptide (46). A few literature reports indicate that mesenchymal cells have the ability to differentiate into neuronal cells. Experiments confirmed the possibility of in vitro transformation of MSCs into mature neurons under the influence of growth factors such as bFGF, EGF, HGF, NT3, GDNF, and BDNF $(47,67)$. However, under the influence of $\beta$-mercaptoethanol, retinoic acid, bFGF, PDGF, forskolin, and heregulin, MSCs differentiated into Schwann cells (69).

\section{Immunomodulatory Functions of MSCs}

Very important functions of MSCs are their immunomodulatory properties. MSCs have the ability to regulate mechanisms of both innate, as well as adaptive immune response, through the modulation of cellular responses and the secretion of inflammatory mediators. The immunomodulation process takes place in many stages and includes: recognition of the inflammatory response and migration of MSCs to the site of injury, "licensing" or activation of MSCs, if necessary, induction of pathogen removal, and modulation of inflammation (40).

MSCs grown in medium supplemented with human serum activate the complement system, which results in their damage (70). MSCs isolated from bone marrow have been shown to have receptors on their surface for complement components such as C3a and C5a. They are chemotactic factors for MSCs and increase their resistance to oxidative stress, as well as the activation of signal pathways responsible for proliferation and anti-apoptotic mechanisms (71). The expression of protectin (CD59) also has been identified on the surface of MSCs and has been shown to secrete factor $\mathrm{H}$. Both molecules inhibit the complement system, which may partially protect MSCs from damage by complement components. They also have been shown to block complement-induced proliferation of peripheral blood mononuclear cells, which is one of the mechanisms of their anti-inflammatory activity $(70,72)$.

Numerous studies have proven that MSCs can regulate the activity of macrophages and microglia cells. MSCs, as well as the supernatant from their culture, stimulate macrophage migration in vitro, and increase their in vivo mobilization to the healing tissue area, accelerating its renewal process (73). Interacting with macrophages, MSCs promote their polarization from the M1 proinflammatory phenotype to M2 anti-inflammatory phenotype cells, reduce the production of pro-inflammatory cytokines such as TNF$\alpha$, IL-1, IL-6, IL12p70, IFN- $\gamma$, and increase secretion of antiinflammatory cytokines, including IL-10, IL-12p40 (74, 75). Francois and co-workers demonstrated that TNF- $\alpha$ and IFN- $\gamma$ activated MSCs, derived from the adult volunteers, suppress T cell proliferation in vitro. This effect was linked to IFN-mediated indoleamine 2,3-dioxygenase (IDO) up-regulation (74). Conversion of monocytes into M2 immunosuppressive macrophages are likely to amplify the overall suppressive effect of MSCs observed in vivo. These findings have been confirmed by Monguio-Tortejada and coworkers who showed that human ATMSCs and UC-MSCs promote polarization of monocytes toward regulatory M2 phenotype (76). The authors demonstrated that MSCs upregulate the CD39 and CD73 expression on monocytes in vitro. The $\mathrm{CD} 39$ and $\mathrm{CD} 73$ regulate the purinergic signaling by the hydrolysis of ATP/ADP to AMP and to adenosine, respectively. This induces the shifts from the pro-inflammatory milieu induced by extracellular ATP into the anti-inflammatory environment regulated by Ado (76). Upregulation of these ectonucleotidases on endogenous monocytes after MSC transplantation would have the advantage of the host monocyte migration and their delivery to the site of inflammation, shifting pro-inflammatory milieu to antiinflammatory environment. In addition, the local treatment with porcine AT-MSCs using an engineered bioactive graft was shown to promote the in vivo CD73 expression on the host monocytes in a swine model of myocardial infarction (76). In vitro studies performed by Giunti et al. revealed that MSCs reduce microglia activation by inflammatory factors. The presence of mouse BMMSCs significantly increase microglial expression and release of molecules associated with a neuroprotective cell phenotype such as CX3CR1, nuclear receptor 4 family, CD200 receptor, and insulin growth factor 1 (77).

MSCs also can modulate neutrophil activity. Experiments have shown that interleukin- 6 produced by MSCs activates signal transducer and activator of transcription 3 factors, which results in increased survival of neutrophils (78), reduces the expression of genes characteristic for cells entering the path of programmed cell death, such as Bax and MCL-1, and also limits the oxygen explosion. On the other hand, IL- 6 reduces the production of reactive oxygen species by neutrophils which weakens the adverse effects of these cells (79). In addition, mesenchymal cells secrete IDO, which inhibits the production of stored 
$\alpha$-denfensin in secretory granules of neutrophils with proinflammatory properties (80). In turn, prostaglandin-2 release by MSCs stimulates macrophages and microglia cells for the production of IL-10, which limits the influx of neutrophils to damaged tissue. Secreted IL-10 also acts on endothelial cells, causing a reduction in E-selectin expression and inhibiting neutrophil migration to the site of injury (78).

Studies also have shown that the co-culture of MSCs with mast cells reduces mast cell degranulation, secretion of proinflammatory cytokines such as TNF- $\alpha$ as well as their migration towards the chemotactic factor. It has been proven that MSCs administered to the inflamed area reduce allergic reactioninduced degranulation and infiltration of this area by mast cells in vivo (81). In the presence of mast cells, MSCs enhance the expression of induced cyclooxygenase-2 (COX-2) and increase the production of PGE-2, which binds to the EP4 receptor on the surface of mast cells. This leads to their deactivation (82). MSCs have $\mathrm{H} 1, \mathrm{H} 2$, and $\mathrm{H} 4$ receptors on their surface that bind histamine - the main mediator secreted by mast cells during an allergic reaction. Their activation leads to an increase in IL-6 production by MSCs, which may affect, among others, regulation of neutrophil survival and migration (83).

Studies to date have shown that MSCs have immunosuppressive effects on natural killer (NK) cells. MSCs inhibit the proliferation of naturally cytotoxic cells, by producing IDO and PGE-2, showing synergistic activity (84). Other experiments indicate that the factor responsible for inhibiting NK cell proliferation is released by MSCs TGF- $\beta$ (85). In addition, MSCs limit IL-2 and IL-15 production, which results in reduced NK cell proliferation and IFN- $\boldsymbol{\gamma}$ production (35). MSCs also have the ability to reduce the expression of NK cell activating receptors, including NKp30, NKp44 and NKG2D, which contribute to a decrease in the cytotoxic activity of these cells and to limit the secretion of pro-inflammatory cytokines (84). Activated NK cells attack MSCs leading to their lysis due to the low level of MHC I expression on their surface. Exposure to interferon $\gamma$ induces an increase in MHC I expression in MSCs which blocks cell cytotoxicity (86).

MSCs interact with dendritic cells (DCs), limiting their functions, including migration capacity, maturation, and antigen presentation. Numerous experiments have confirmed that MSCs reduce the expression of markers of mature DCs including MHC class II molecules, CD40, CD80 and CD86 and modulate the expression of markers of "DCs deposition" in lymph nodes, including CCR7 chemokines (87). Studies by Li et al. have shown that regulation of DC maturation can be mediated by cytokines produced by MSCs, such as IL-6, or by direct contact using the Notch signaling pathway (88). MSCs also can affect the transformation of immature DCs into mature forms. They block DC maturation by secreting PGE-2 (89). MSCs have the ability to change the phenotype of DCs to antiinflammatory. DCs under the influence of MSCs increase the secretion of anti-inflammatory cytokines, including IL-10, decrease the production of pro-inflammatory cytokines such as IL-12 and TNF- $\alpha$ and increase their phagocytic activity. In addition, experiments by Zhang et al. have shown that phenotypically altered DCs inhibit hypersensitivity reactions in vivo $(90,91)$, and are not able to activate T helper (Th) cells (92); instead they induce the formation of antigen-specific $\mathrm{T}$ regulatory (Treg) cells (88) (Figure 1).

MSCs can modulate the action of secondary immune response cells. One of the tasks of MSCs is maintaining a proper balance between Th1 and Th2 phenotype CD4 T cells. Numerous in vitro and in vivo studies have shown that MSCs activate the change of CD4 $\mathrm{T}$ cells with a Th1 inflammatory phenotype, secreting IL- $1 \alpha$, IL- $1 \beta$, IFN- $\gamma$, and TNF- $\alpha$ into Th2 anti-inflammatory phenotype cells producing IL-3, IL -4, IL-5, IL-10, and IL-13 $(93,94)$. Conversely, in allergic diseases, MSCs reduce the production of Th2 dependent cytokines and increase the secretion of Th-1-dependent cytokines, which provides an appropriate balance and protects in allergic respiratory diseases (95). In addition, MSCs, by secreting indoleamine 2,3dioxygenase and prostaglandin E-2, inhibit the differentiation of IL-17-producing Th17 lymphocytes, in favor of the formation of Th2 lymphocytes and Treg lymphocytes $(93,96)$. The TGF- $\beta$ produced by MSCs plays an important role in maintaining an appropriate balance between the Th1, Th2 and Th17 helper lymphocytes and regulatory lymphocytes (97).

Another cells affected by MSCs are CD8 T cells. By suppressing Th1 and Th17 lymphocytes necessary for the activation of CD8 T cells, MSCs contribute to the suppression of these cells (78). Experiments have shown that MSCs can also directly prevent the cytotoxic activity of CD8 lymphocytes, mainly by blocking their proliferation rather than by inhibiting the cytotoxic effect (98).

As a result of direct contact with MSCs or through factors produced by them, such as IDO, PGE-2, and TGF- $\beta$, the formation of antigen-specific regulatory $\mathrm{T}$ cells occurs. In vitro studies have shown that Treg cells affect $\mathrm{Th}$ lymphocytes with a pro-inflammatory phenotype causing inhibition of their proliferation (99). In contrast, IL-4 and IL13 produced by Th2 lymphocytes stimulate MSCs to produce TGF- $\beta$, which is an important factor that stimulates regulatory $\mathrm{T}$ cells (97). In addition to the aforementioned factors, nitric oxide, galectin-1, and semaphorin-3A produced by MSCs stimulate lymphocyte differentiation toward Treg (48). Treg activation is also the main mechanism induced by MSCs enabling the acceptance and survival of allogeneic transplants (100), as well as protection against some autoimmune and allergic reactions (40).

Mesenchymal cells also affect B lymphocytes, retaining them in the G0/G1 phase, limiting their chemotactic activity (101). Studies have shown that MSCs have the ability to reduce the activity, differentiation and proliferation of B lymphocytes via the PD-1 signaling pathway (102). In addition, MSCs act as a suppressor on CD4 $\mathrm{T}$ cells, resulting in reduced production of the CD40L co-stimulatory molecule and inability to activate $\mathrm{B}$ cells (78). The experiments of Corcione et al. have shown that MSCs have the ability to inhibit the production of antibodies (101). Other researchers have described the possibility of MSCs stimulating proliferation and B cell differentiation (103) (Figure 2). 

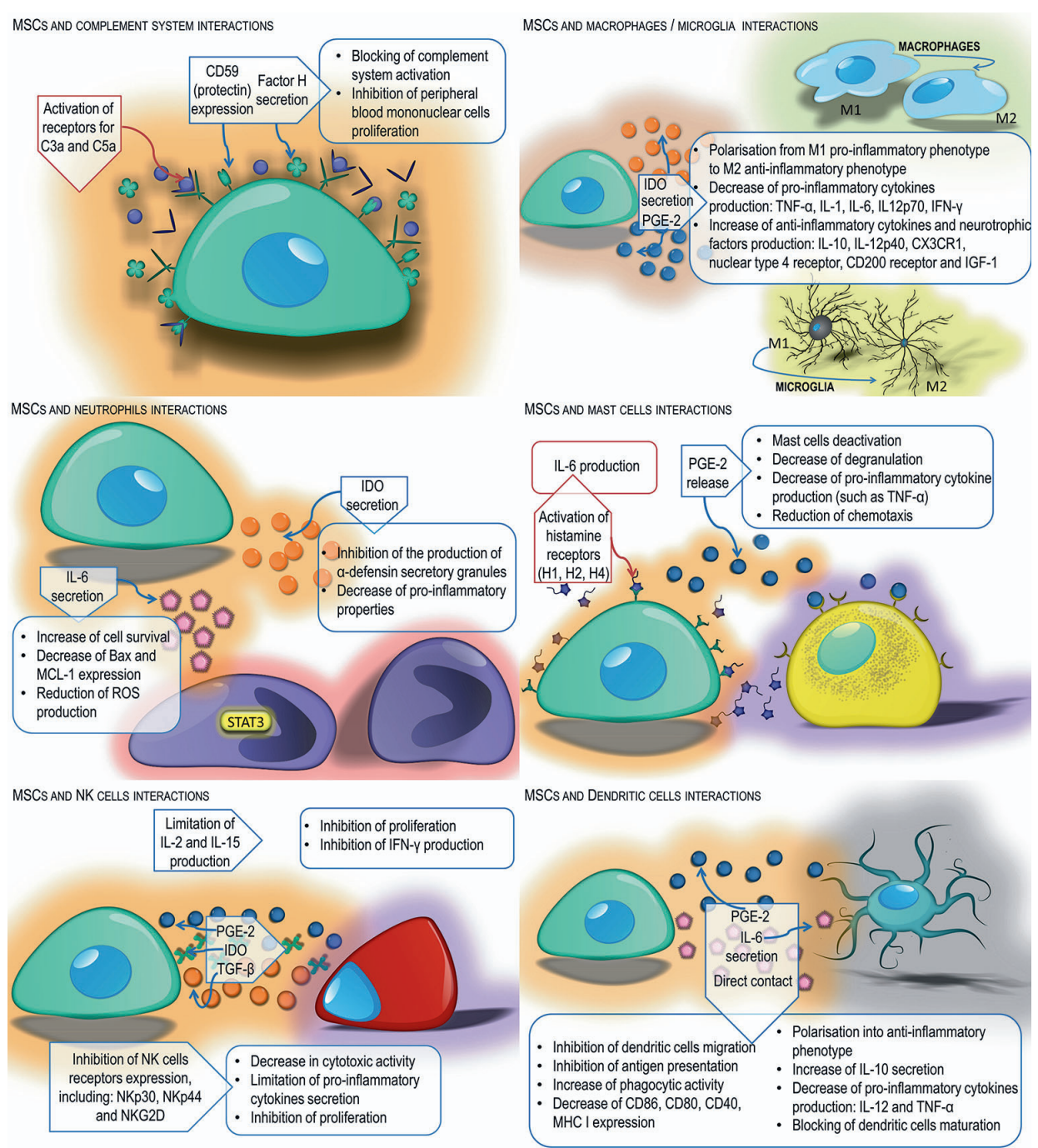

MSCS AND DENDRITIC CELLS INTERACTIONS

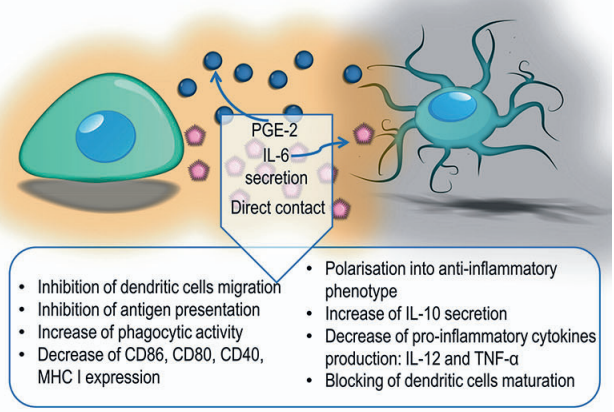

FIGURE 1 | Interactions of MSCs with innate immune cells. MSCs exert immunomodulatory effects on neutrophils, NK cells, macrophages/microglia, mast cells, and dendritic cells through secretion of various soluble factors or direct cell-cell interaction.

\section{Extracellular Vesicles}

In addition to direct actions, MSCs can modify the functions of the microenvironment through the release of extracellular vesicles. MSCs transmit numerous proteins, including cytokines, chemokines and growth factors, membrane receptors, lipids and various types of nucleic acids through EVs, thus protecting and regenerating the damaged cells and mitigating the immune response. EVs are thought to play a key role in intercellular communication. The Nobel Prize in Physiology and Medicine in 2013 was awarded for the discovery of transport between cells in vesicles (104).

\section{Types of EVs}

EVs are membrane structures secreted by cells, including MSCs. They constitute a heterogeneous population consisting of several types of EVs differing in origin, size, shape and content.
According to the classic nomenclature, we can distinguish three main types: exosomes, microvesicles and apoptotic bodies (105). Exosomes are currently the most thoroughly described type of EVs: $30 \mathrm{~nm}$ to $120 \mathrm{~nm}$ in size, spherical in shape and with a two-layer lipid film. They constitute a homogeneous population of EVs, and their optical density is from 1.13 to $1.19 \mathrm{~g} / \mathrm{cm}^{3}$. Exosomes are formed by the convexity of endosomal membranes in late endosomes, resulting in the formation of multi-alveolar bodies, which by connecting with the cytoplasmic membrane, cells release their content to the outside in the form of exosomes (106). This type of EV is characterized by the presence of many proteins, including annexin, tetraspanin (CD63, CD81, CD9), heat shock proteins, clarins, caveolin, exosome specific proteins such as Alix and Tsg101, and proteins typical of cells from which they come (107-109). In addition, exosomes contain characteristic lipids, including: 

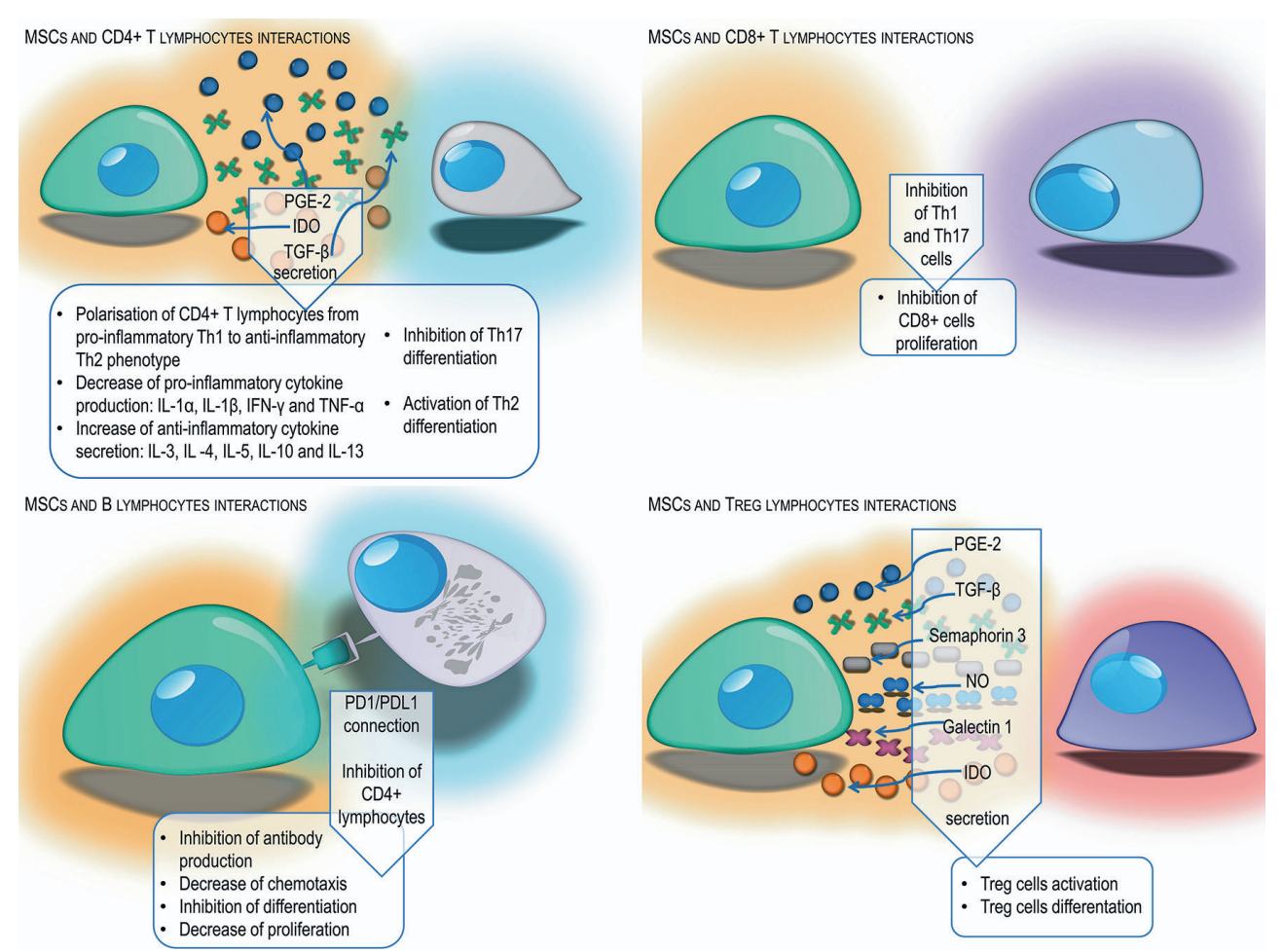

FIGURE 2 | Schematic representation of different mechanisms used by MSCs to suppress the adaptive immune response from T and B lymphocytes by cell-cell interaction and secretion of different factors.

fragments of lipid raft-GM1 ganglioside, cholesterol, ceramides, sphingomyelin, and phosphatidylserine, as well as nucleic acids: mRNA and microRNA (miRNA) $(110,111)$.

The second type of EVs is microvesicles called ectosomes or budding vesicles. They range in size from $100 \mathrm{~nm}$ to $1 \mu \mathrm{m}$, are a heterogeneous population of irregular shape, and their optical density is not well defined. Microvesicles arise directly from the cell's cytoplasmic membrane, by budding from the membrane surface, and then separating the resulting structures, similar to the detachment that occurs during cytokinesis (112). Microvesicles do not contain proteins involved in the process of endocytosis, but show the presence of integrins, flotillins, selectins, metalloproteinases, CD40 proteins, and some of them have proteins typical of so-called exosomes: tetraspanin. In addition, they are rich in lipids, have large amounts of phosphatidylserine and cholesterol, as well as sphingomyelin and ceramides, and also accumulate nucleic acids: mRNA and miRNA $(105,110)$.

The third type of EVs is apoptotic bodies also called apoptotic vesicles. They range in size from $50 \mathrm{~nm}$ to $4 \mu \mathrm{l}$, most of them over $1 \mu \mathrm{m}$, and they are characterized by irregular shape (113). The optical density of apoptotic bodies ranges from 1.16 to $1.28 \mathrm{~g} /$ $\mathrm{cm}^{3}$; they are formed from dying cells that are in the late stage of the process of apoptosis. Inside they contain histones, fragments of organelles and cell membranes, nucleic acids: mRNA, miRNA and DNA, have a high concentration of phosphatidylserine, and their membranes are permeable (112).

\section{Composition of EVs}

EVs contain numerous compounds in their interior, including: proteins, lipids and nucleic acids. The secretome of EVs released by MSCs are not constant due to the heterogeneity of the cell population, isolation methods, different cell passages or sources from which they are isolated (114). Proteomic analysis of EVs isolated from MSCs from various sources allowed the identification of their proteins' characteristics (115). Proteins transported with EVs are involved in cell-to-cell signaling, cell adhesion, angiogenesis, apoptosis, and immune responses. Previous studies have shown that EVs contain tetraspanins and MSC-typical proteins, surface receptors and signaling molecules involved in self-renewal and cell differentiation (116). In addition, EVs accumulate RAB proteins that regulate the transport and attachment of EVs to cells (117). Various types of biologically active lipids are located in EVs. EV membranes originate from various sources, are rich in lysobiphosphatidic acid molecules that regulate the microvesicles detachment process, as well as in lipid raft lipids, including cholesterol, ceramides, sphingolipids and glycophospholipids (118). In addition, EVs contain lipid mediators, such as prostaglandins, the enzymes responsible for $\mathrm{EV}$ formation, including phospholipases A2, C and D and free fatty acids e.g., arachidonic acid (119). RNA molecules are another important component of EVs from various cell types. The most common RNA types present in all types of EVs include mRNA and miRNA (120). A large amount of transporting RNA was 
observed in EVs derived from MSCs. In addition, ribosomal RNA is present in EVs, varying in number depending on the cell type (121). Recent research also indicates the content of small, non-coding RNA molecules in EVs - piwi-interacting RNA (122). Moreover, many studies have shown that miRNA is the type of RNA involved in MSC-exosome-mediated functional activity (123). It was reported that the transfer of miR-125a and miR-30b induce the tube formation of human umbilical vein endothelial cells, promoting the process of angiogenesis (124, 125). On the other hand, MSC-exosomes contain miR-100 which targets to VEGF in breast cancer cells and determines the antiangiogenic effect in a tumor microenvironment (126). Other authors proved that exosomal miR-181c and miR-146a have immunomodulatory properties by a downregulation of the Tolllike receptor-4 signaling pathway (127) and an enhancement of M2 macrophages polarization (128). Moreover, miR-233 is responsible for an anti-apoptotic effect of MSC-exosomes and the cardioprotection in sepsis (129). MSC-exosomes contains also miRNA such as: miRNA-181-5p (130) and miR-122 (131) revealing an anti-fibrotic effect in liver fibrosis. Recently it was shown that exosomal miR-124 promote cell proliferation and liver regeneration via inhibiting Foxg1 after partial hepatectomy in rats (132).

\section{Immunomodulatory Functions of EVs Derived From MSCs In Vitro}

The immunomodulatory properties of MSCs, which have been the subject of many in vitro studies, appear to be associated with extracellular vesicles secreted by the cells. It has been shown that EVs released from MSCs have the ability to inhibit the proliferation and differentiation of B lymphocytes, as well as their action is dosedependent (133). Similarly, dose-dependent inhibition of IgM, IgG, and IgA production by extracellular vesicles derived from mesenchymal cells has been demonstrated. Mokarizadeh et al. observed that EVs produced by murine BM-MSCs have the ability to inhibit the proliferation of syngeneic and allogeneic $\mathrm{T}$ lymphocytes, induce apoptosis of activated $\mathrm{T}$ lymphocytes, increase in the number of regulatory $\mathrm{T}$ lymphocytes and enhance the secretion of anti-inflammatory cytokines: IL-10 and TGF- $\beta 1$ (134).

Other authors have shown that galectin-1 and programmed death receptor ligand (PD-L1) were present not only on the surface of MSCs but also on EVs derived from MSCs (135). Galectin-1, which is endogenous leptin, has been reported to induce apoptosis of activated T lymphocytes and stimulate maturation of regulatory T lymphocytes $(136,137)$. In contrast, PD-L1, which is a ligand of the $\mathrm{PD}-1$ receptor, induces the proliferation and activity of regulatory $\mathrm{T}$ cells. In addition, EVs derived from mesenchymal stem cells contained TGF- $\beta$, which also activates regulatory $\mathrm{T}$ cell formation (138).

\section{Protective/Pro-regenerative and Immunomodulatory Properties of EVs Derived From MSCs In Vivo}

EVs derived from MSCs (MSC-EVs) have shown protective, regenerative and immunomodulatory properties in animal models in vivo. The therapeutic potential of EVs has been pursued in several disease settings. The most commonly studied models of organ injury for MSC-EV therapy are myocardial ischemia and ischemic stroke.

Coronary artery diseases lead to blockage of blood flow followed by ischemia and reperfusion injury. Exosomes obtained from MSCs have shown a protective effect on myocardial cells damaged as a result of acute myocardial infarction. Intravenous infusion of MSC conditioned media before reperfusion reduced infarct size in mouse and pig models of myocardial/reperfusion (MI/R) injury (139, 140). Infarct size reduction in MI/R injury is attained by enhanced cardiomyocyte viability. EVs derived from human MSCs conditioned media reduce oxidative stress and activate prosurvival signaling in cardiac cells preventing adverse cardiac remodeling after MI/R damage. Moreover, EV-treated animals exhibited lower white blood cells counts in the peripheral blood and reduced neutrophil and monocyte influx into the hearts compared to control animals after MI/R injury (141). Administration of MSC-EVs was shown to inhibit apoptosis in cardiomyocytes in a mouse model of acute myocardial infarction (142). Similarly, Sun et al. have shown that MSC-EVs reduced cardiomyocyte apoptosis in an experimental model of dilated cardiomyopathy (143). The authors revealed that intravenous injection of MSC-EVs regulates the balance between two subsets of macrophages observed in the hearts of mice subjected to dilated cardiomyopathy. MSC-EVs decreased the number of proinflammatory M1-like macrophages while increasing the number of anti-inflammatory M2-like macrophages. The observed switch of macrophages to an anti-inflammatory state changed the cytokine profiles reducing inflammatory cytokines such as IL1 , IL-6, and TNF- $\alpha$ in serum of dilated cardiomyopathy mice after MSC exosome treatment (143). In a recent study, performed by Wei et al. administration of MSC-EVs carrying miR-181a reported to decrease the expression of proinflammatory cytokines such as IL- 6 and TNF- $\alpha$ while enhanced the expression of anti-inflammatory IL-10 in mouse heart tissues after MI/R insult (144). Moreover, it was shown that the number of $\mathrm{T}$ regulatory cells detected locally was much higher in MSC-EVs or miR-181a overexpressed EV treated mice than the control group subjected to acute myocardial infarction. Additionally, MSC-EVs enriched with miR-19a and miR-221 injected into the border of an ischemic heart region reduced apoptosis downregulating Sema3A and activator of transcription 3 genes regulated cell death $(129,145)$. Intra-myocardial infusion of MSC-EVs improved cardiac function preserving cardiac systolic and diastolic performance in $M I / R$ rats and mice assessed by echocardiography (146-148). EVs induce neovascularization in ischemic heart disease associated with proliferation and migration of endothelial cells. MSC-EVs treatment revealed significantly higher density of capillaries in infarcted hearts than control animals one month after MI/R injury $(146,147)$. It was shown that MSC-EVs carry high levels of proangiogenic factors i.e., extracellular matrix metalloproteinase inducer (EMMPRIN) and thus may promote angiogenesis (149). The studies revealed that MSC-EVs contain also such pro- 
angiogenic factors as: PDGF-D, EGF, FGF, VEGF and SCF (150). Moreover, it was revealed that the main mechanisms responsible for the enhancement of angiogenesis by MSC-EVs are activation of NFKB signaling pathway, transfer of STAT1 and induction of Wnt4/ $\beta$-catenin signaling pathway (150-152).

EV delivery also offers neuroprotective, neurorestorative, and immunomodulatory effects in neurological diseases. MSC secretome therapy significantly reduced neuronal loss and apoptosis caused by traumatic brain injury (TBI) in rats (153). EV treatment increased the number of newly generated neuroblasts and mature neurons in dentate gyrus and ischemic zones of the brains as well as reduced inflammation in TBI rats (154). MSC-derived EVs from different sources selectively promote neurite growth and remodeling (155-157). It also promotes cerebral endothelial proliferation and new capillary network arrangement assisting in the reconstruction of damaged CNS tissues. Enhanced neurogenesis and angiogenesis observed in MSC-EV recipients positively correlated with spatial learning and memory impaired in mice and rats subjected to stroke (158160). Moreover, Kim et al. demonstrated that intravenously infusion of EVs after induction of TBI in mice diminished the levels of pro-inflammatory cytokine IL-1 $\beta$ in brain tissue (159). Systemically injected MSC-EVs after ischemic stroke or TBI also improve functional outcome. Delivery of MSC-EVs reduces post-ischemic motor coordination deficits $(154,161)$. This functional recovery is associated with axonal sprouting, fiber integrity, oligodendrogenesis and re-myelination in experimental models of stroke $(162,163)$. Furthermore, MSCEV treatment reduces brain inflammation after brain injury in rats, decreasing microgliosis and preventing reactive astrogliosis (162). In another very recent study, intra-arterial transplantation of EVs from human BM-MSCs led to decrease of proinflammatory cytokines: IL- $1 \alpha$, IL- $1 \beta$, IL-6, TGF- $\beta 2$, and chemokines: CXCL1, MIP-1 $\alpha$, MIP- $3 \alpha$, and MCP-1 in the striatum of focal ischemic brain injured rats (164). Additionally, it was reported that MSC-EVs have neuroprotective effect in a preclinical model of fetal hypoxicischemic brain injury. The study revealed that MSC-EVs improved the structural and functional outcome by preventing hypomyelination, decreasing the number and duration of seizures, and by protecting baroreceptor reflex sensitivity (165). MSC-EVs could facilitate spinal cord injury healing. EVs isolated from human umbilical cord MSCs injected systemically into mice model of spinal cord injury improved functional recovery in transplant recipients (166). Similarly, Lu's research revealed that MSC-EVs intravenous infusion in rats with spinal cord injury exhibited significant improvements in locomotors functions compared with EV-free group (167). Moreover, MSC-derived EVs alleviated inflammatory response after spinal cord injury in mice triggering polarization of macrophages from pro-inflammatory M1 to pro-repair M2 phenotype and reducing pro-inflammatory cytokine level of TNF- $\alpha$, IL-6, MCP-1, and MIP-1 $\alpha$ while increasing anti-inflammatory cytokines: IL- 4 and IL-10 in injured spinal cord tissue (166). Similarly, MSC-EVs attenuate inflammation in rat model of spinal cord injury resulting in the decrease of reactive microglia and astrocytes
(168). The effect was accompanied by the expansion of suppressor cells in the blood and spleen of EV recipients.

It has been shown that MSC-EVs ameliorate liver injury as well. In lethal hepatic failure in mice, systemic administration of human MSC-EVs decreased hepatic necrosis and prolonged survival of animals (169). Similarly, BM-MSC secretome attenuated hepatocyte apoptosis and diminished liver damage induced by $\mathrm{CCl}_{4}$ in rats (170). MSC-EVs protected the liver from hypoxia-induced injury or from ischemia-reperfusion harm. Mice that received the injection of MSC-derived EVs before the ischemia revealed hepatocyte proliferation demonstrated by an increased number of Ki-67-positive cells and decrease of the expression of inflammation-associated genes (171). Similarly, immunosuppressive effect of MSC-EVs on liver injury animal model was reported by Tamura et al. The expression of mRNA for pro-inflammatory cytokines: IL-1, IL- 2 , TNF- $\alpha$, IFN- $\gamma$ was reduced while anti-inflammatory cytokines: TGF- $\beta$ and HGF, and the number of $\mathrm{T}$ regulatory cells increased in the liver tissue (172).

The therapeutic efficacy of MSC-EVs for acute or chronic kidney disease has been proven experimentally. Bruno et al. proved that EVs isolated from human mesenchymal bone marrow stem cells support epithelial cell survival in acute renal failure, stimulating their proliferation and preventing apoptosis (173). In an animal model of renal ischemia/reperfusion injury, EVs have been shown to decrease epithelial/reperfusion injury. EVs have been shown to decrease epithelial tubular cell damage and increase cell proliferation and kidney function $(174,175)$. Some studies have shown that the renoprotective effect of EVs is caused by kidney neovascularization. Infusion of EVs improved renal capillary density and reduced kidney fibrosis in a rat model of acute kidney injury (176). Recent studies have shown that MSC-EVs also have a beneficial effect in treatment of druginduced nephropathy inhibiting mitochondrial apoptosis in epithelial tubular cells and inducing cell proliferation (177). Moreover, in several preclinical studies of kidney injury animal models MSC-EVs therapy reduced inflammation by decreasing the presence of inflammatory cytokines: IL- $1 \beta$, IL- 6 , and TNF- $\alpha$ (178-180).

The use of MSC-derived EVs has been shown to have a therapeutic effect in several experimental models of lung diseases. MSC-derived EVs infused into mice in an acute lung injury model induced by $\mathrm{E}$. coli endotoxin restored protein permeability and increased fluid clearance in the alveolus (181, 182). Similarly, in a pig model of influenza virus-induced acute lung injury, intra-tracheal infusion of MSC-EVs alleviated lung lesions, inhibiting apoptosis of influenza-infected lung epithelial cells. In addition, MSC-EVs exhibited an immunomodulatory effect suppressing TNF- $\alpha$ and increasing IL-10 secretion in the alveolus after injury (183). MSC secretome therapy also has shown promise in chronic progressive respiratory disease which accompanies idiopathic pulmonary fibrosis. Human BM-MSCEVs infused intravenously into bleomycin-induced pulmonary fibrotic mice restored collagen content, improved pulmonary morphology and restored lung architecture (184). Moreover, systemic administration of MSC-derived EVs modulate 
immune response by the decrease of inflammatory cell influx and altering alveolar macrophages toward an anti-inflammatory phenotype (184, 185). The beneficial effect of MSC-EVs injection was confirmed on ex vivo perfused human model of bacterial pneumonia. It was revealed that microvesicles derived from MSCs enhanced the alveolar fluid clearance and reduced lung protein permeability; additionally pretreatment of MSCs with polyinosinic:polycytidylic acid improved the antimicrobial activity of microvesicles (186).

Beneficial effects of MSC-EVs have been observed in wound and bone healing. Local multi-point injection of EVs around burn wound animal models promoted re-epithelialization, enhanced angiogenesis and accelerated wound closure (187, 188). Application of human MSC-EVs into femoral fractures in mice accelerated fracture healing (189). Similarly, repeated injections of EVs prepared from human MSCs promoted regeneration of osteochondral defects in a rat femur injury model (190). Recently, MSC-EVs combined with various scaffold materials have been shown to encourage bone repair in rodent calvarial bone defects enhancing angiogenesis and osteogenesis (191, 192).

EVs isolated from MSCs used in the model of inflammatory bowel disease induced by tri-nitrobenzene sulfonic acid injection in rats, EVs derived from rat BM-MSCs attenuated colonic inflammation via a markedly decrease in IL-1 $\beta$ and an increase in IL-10 expression (193). A similar study showed that human umbilical cord MSC-EVs reduced TNF- $\alpha$, IL-1 $\beta$, IL-6, iNOS, and IL-7 genes while increasing the expression of IL-10 gene in the colon tissues relieving inflammatory bowel disease's symptoms in mice with dextran sulfate sodium induced colitis (194).

The therapeutic potential of MSC-EVs also has been proven in various animal models of organ and tissue injury including immune-related conditions i.e. graft-versus-host disease (GVHD), autoimmune diseases, sepsis etc. Adipose derived MSC-EVs infusion in a rat model of sepsis induced by cecal ligation lowered the levels of inflammatory mediators: IL- $1 \beta$, TNF- $\alpha$, MMP-9, NF- $\kappa$ B in lungs and kidneys of experimental animals (195). In murine models of acute GVHD, MSC-EVs reduced the number of cytotoxic cells and decreased the serum levels of IL-2, TNF- $\alpha$ and IFN- $\gamma$ in peripheral blood $(196,197)$.

Immunomodulatory effects of EVs have been reported in a few studies of autoimmune diseases. Bai et al. showed the ameliorative effect of local administration of MSC-derived exosomes in inhibiting migration of inflammatory cells to the retina and the significant reduction in IL-17- and IFN- $\gamma-$ producing $\mathrm{T}$ cell subsets along with the significant increase in the CD25+Foxp3+ $\mathrm{T}$ regulatory cells in a rat model of experimental autoimmune uveitis (198). A recent study of MSC-EVs infusion into streptozotocin-induced of the type 1 diabetes mellitus mice reported by Nojehdehi et al. demonstrated the decrease of IL-17 and IFN- $\gamma$ levels with the elevation of antiinflammatory cytokines: IL-4, IL-10, and TGF- $\beta$ in concordance with the significant increase in the Treg cell ratio in the spleen of EVs treated mice (199) (Figure 3).

The overview of 59 experimental studies with the administration of MSC-EVs in the different diseases models was presented in Table 1. The analysis revealed that the most frequently applied source of MSC-EVs was bone marrow (38 studies). At the second place MSC-EVs from umbilical cord and adipose tissue were used (10 studies and 6 studies, respectively). Less frequently other sources were applied such as: umbilical cord blood, embroynic stem cells, cardiac progenitors, myocardium, menstrual fluid, choroin, and embryo. Moreover, the analysis revealed that the most frequently used type of injected vesicles were exosomes which were examined in 29 studies. At the second place, the whole fraction of extracellular vesicles was applied, explored by 23 research groups. Microvesicles were analyzed only in 6 out of 59 studies. Importantly, only 11 studies investigated vesicles immobilized on scaffolds or derived from genetically modified cells; whereas 48 studies focused on naive, unmodified vesicles.

The above mentioned studies showed that in the most studies human MSC-EVs were applied (40 studies). Subsequently, rat MSC-EVs (10 studies), mouse MSC-EVs (7 studies) and swine MSC-EVs (2 studies) were administrated. The effect of transplanted MSC-EVs was most commonly explored in mouse and rat experimental models (28 and 26 researches, respectively). Rarely, the human, ovine and swine models were investigated (2, 1 and 3 studies, respectively). Regarding the compatibility of MSC-EVs' injection into the different models, the most frequently used was xenogenic transplantation, applied in 38 of presented studies, showing no adverse effects. This confirms the safety of application of MSC-EVs derived from the different donors to the host without requiring immunological compatibility. Then, 19 allogenic and 2 autologous administrations were used in the referred studies.

Up to now, the most frequently used method for MSC-EVs isolation was differential ultracentrifugation utilized in 42 referred investigation. In many research studies, this technique was combined with other methods such as: filtration, precipitation or density gradient separation. Other commonly used techniques were: precipitation or its combination with the other techniques (7 studies), filtration or its combination with other methods (6 studies) or application of exosome isolation kit (6 studies). The isolated MSC-EVs were assessed according to the measurement of the level of proteins (39 studies), the number of particles (8 studies) or the number of cells from which EVs derived (18 studies). Moreover, the analysis showed that the most frequently used administration route of EVs was intravenous injection, applied in 32 studies. Alternatively, MSC-EVs were administered using many other routes such as: intracardiac (eight studies), intraperitoneal (three studies), subcuntaneous (three studies), intratracheal (three studies), local injection (three studies), or intra-renal infusion (two studies). Finally, intracerebral, intra-arterial, intranasal, intraarticular, and periocular route of EVs' administration were applied in individual cases of referred studies.

\section{MSC-EVs in Clinical Trials}

Inspired by promising results of therapeutic effect of MSC-EVs observed in preclinical studies, the first clinical trials using MSCEVs were established. Currently, over 100 clinical studies 


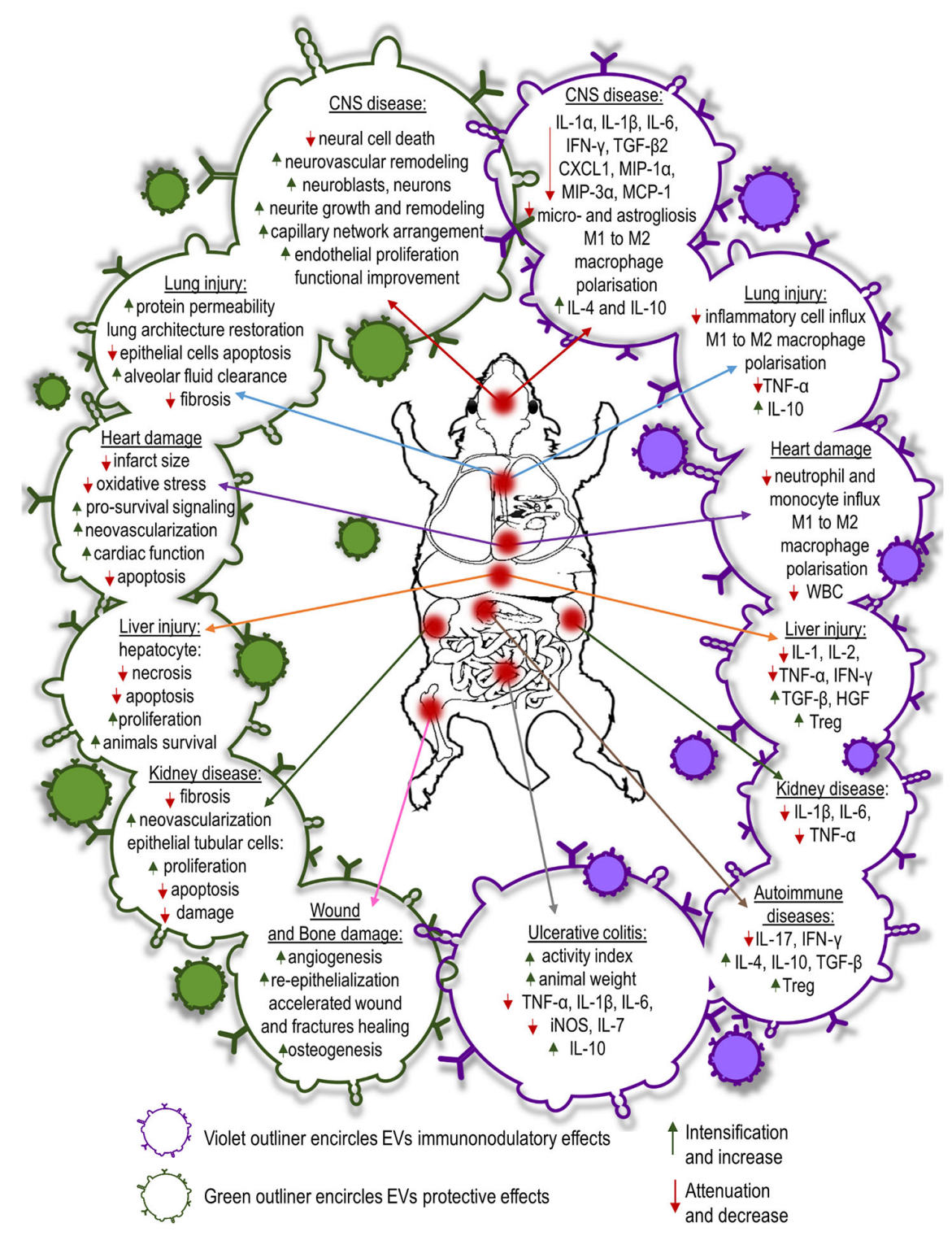

FIGURE 3 | Summary of protective, regenerative or immunomodulatory capabilities of MSC-EVs administered in experimental models of different diseases.

involving exosomes are listed in www.clinicaltrials.gov. The majority of these trials focus on the use of endogenous exosomes for diagnostic purposes. However, the number of clinical applications of MSC-EVs is rather scanty $(200,201)$.

The first case report of application MSC-EVs was published by Kordelas et al. in 2014. Individual treatment with the exosomes isolated from the supernatant of allogeneic BMMSCs has been applied to therapy-refractory GVHD patient. Four doses of MSC-EVs obtained from the supernatant of $4 \times$ $10^{7}$ BM-MSCs were administered every 2 to 3 days. Clinical symptoms improved significantly shortly after treatment. The cutaneous and mucosal GVHD showed remarkably response after 2 weeks and it was stable for several months following MSC-EVs infusion. MSC-EVs therapy allowed to reducing the dosage of steroids from $125 \mathrm{mg} / \mathrm{d}$ to $30 \mathrm{mg} / \mathrm{d}$. Also, the reduced pro-inflammatory cytokine response of the patient PBMN was observed following the third dose of MSC-EVs (202).

Katagiri et al. published the first clinical report of alveolar bone regeneration with the secretome derived from allogeneic BM-MSCs (Lonza). The clinical trial was undertaken to evaluate the safety and therapeutic effect of MSC-CM in patients with severe bone resorption due to periodontitis who need bone augmentation prior to dental implants. Conditioned medium from BM-MSCs soaked to collagen sponge was implanted at the laterally maxillary sinus wall in 8 patients. No local or systemic complications were reported. Radiographic evaluation followed by histological assessment performed 6 months later revealed early bone formation in all cases. Furthermore, infiltration of 
TABLE 1 | Overview of an application of MSC-EVs in experimental studies.

\begin{tabular}{|c|c|c|c|c|c|c|c|c|c|c|c|}
\hline Disease & $\begin{array}{l}\text { MSC-EVs' } \\
\text { source }\end{array}$ & $\begin{array}{l}\text { MSC-EVs' } \\
\text { type }\end{array}$ & $\begin{array}{l}\text { MSC-EVs' } \\
\text { modification }\end{array}$ & $\begin{array}{l}\text { MSC-EVs' } \\
\text { isolation } \\
\text { procedure }\end{array}$ & Donor & Compatibility & Host & $\begin{array}{l}\text { MSC-EVs' } \\
\text { dose }\end{array}$ & $\begin{array}{l}\text { Administration } \\
\text { route }\end{array}$ & Main effect & Ref.Nr \\
\hline $\begin{array}{l}\text { Myocardial } \\
\text { ischemia/ } \\
\text { reperfusion } \\
\text { injury }\end{array}$ & $\begin{array}{l}\text { Embryonic } \\
\text { stem cells }\end{array}$ & Exosomes & No & $\begin{array}{l}\text { Size-exclusion } \\
\text { fractionation on a } \\
\text { HPLC + filtration }\end{array}$ & Human & Xeno & Mouse & $0.4 \mu \mathrm{g}$ & Intravenous & - Reduction of infarct size & (139) \\
\hline $\begin{array}{l}\text { Myocardial } \\
\text { ischemia/ } \\
\text { reperfusion } \\
\text { injury }\end{array}$ & $\begin{array}{l}\text { Embryonic } \\
\text { stem cells }\end{array}$ & $\begin{array}{l}\text { Conditioned } \\
\text { medium }\end{array}$ & No & - & Human & Xeno & Pig & $2.0 \mathrm{mg}$ & $\begin{array}{l}\text { Intravenous, } \\
\text { Intracardiac }\end{array}$ & $\begin{array}{l}\text {-Reduction of myocardial nuclear oxidative stress } \\
\text {-Reduction of TGF-beta signalling and apoptosis } \\
\text {-Reduction in infarct size } \\
\text {-Improvement of systolic and diastolic cardiac } \\
\text { performance }\end{array}$ & (140) \\
\hline \multirow[t]{2}{*}{$\begin{array}{l}\text { Myocardial } \\
\text { ischemia/ } \\
\text { reperfusion } \\
\text { injury }\end{array}$} & \multirow[t]{2}{*}{$\begin{array}{l}\text { Embryonic } \\
\text { stem cells }\end{array}$} & \multirow[t]{2}{*}{ Exosomes } & \multirow[t]{2}{*}{ No } & \multirow[t]{2}{*}{$\begin{array}{l}\text { Size-exclusion } \\
\text { fractionation on a } \\
\text { HPLC + Ffltration }\end{array}$} & \multirow[t]{2}{*}{ Human } & \multirow[t]{2}{*}{ Xeno } & \multirow[t]{2}{*}{ Mouse } & \multirow[t]{2}{*}{$\begin{array}{l}16 \mu \mathrm{g} / \mathrm{kg} \\
4 \mu \mathrm{g} / \mathrm{kg} \\
1 \mu \mathrm{g} / \mathrm{kg}\end{array}$} & \multirow[t]{2}{*}{ Intravenous } & $\begin{array}{l}\text {-Reduction of infarct size } \\
\text {-Significant reduction of local and systemic } \\
\text { inflammation }\end{array}$ & \multirow[t]{2}{*}{ (141) } \\
\hline & & & & & & & & & & $\begin{array}{l}\text {-Restoration of bioenergetics, reduction of oxidative } \\
\text { stress, activation of pro-sunvival signalling }\end{array}$ & \\
\hline $\begin{array}{l}\text { Myocardial } \\
\text { ischemia/ } \\
\text { reperfusion } \\
\text { injury }\end{array}$ & $\begin{array}{l}\text { Cardiac } \\
\text { progenitors }\end{array}$ & Exosomes & No & $\begin{array}{l}\text { Filtration }+ \\
\text { precipitation }\end{array}$ & Mouse & Allo & Mouse & $\begin{array}{l}\text { from } 5 \times 10^{5} \\
\text { MSCs }\end{array}$ & Intracardiac & $\begin{array}{l}\text {-Enhancement cardiac function and geometry } \\
\text {-Inhibition of cardiomyocyte apoptosis }\end{array}$ & (142) \\
\hline $\begin{array}{l}\text { Dilated } \\
\text { cardiomyopathy }\end{array}$ & $\begin{array}{l}\text { Bone } \\
\text { marrow }\end{array}$ & Exosomes & No & $\begin{array}{l}\text { Differential } \\
\text { ultracentrifugation }\end{array}$ & $N Q$ & & Mouse & $300 \mu \mathrm{g}$ & Intravenous & $\begin{array}{l}\text {-Improvement of cardiac function, attenuation of } \\
\text { cardiac dilation, cardiomyocytes apoptosis } \\
\text {-Reduction of expression levels of inflammatory } \\
\text { factors, decrease of the inflammatory cells } \\
\text { - Attenuation of the pro-inflammatory } \\
\text { macrophages }\end{array}$ & $(143)$ \\
\hline $\begin{array}{l}\text { Myocardial } \\
\text { ischemia- } \\
\text { reperfusion } \\
\text { injury }\end{array}$ & $\begin{array}{l}\text { Umbilical } \\
\text { cord blood }\end{array}$ & Exosomes & $\begin{array}{l}\text { miRNA-181a } \\
\text { over- } \\
\text { expressing- } \\
\text { exosomes }\end{array}$ & $\begin{array}{l}\text { Differential } \\
\text { ultracentrifugation } \\
+ \text { filtration }\end{array}$ & Human & Xeno & Mouse & $200 \mu \mathrm{g}$ & Intracardiac & $\begin{array}{l}\text { - Immune-suppressing effect of miRNA-181a } \\
\text { exosomes } \\
\text { - Stronger therapeutic effect of miRNA-181a } \\
\text { exosomes }\end{array}$ & (144) \\
\hline $\begin{array}{l}\text { Polymicrobial } \\
\text { sepsis }\end{array}$ & $\begin{array}{l}\text { Bone } \\
\text { marrow }\end{array}$ & Exosomes & No & $\begin{array}{l}\text { Filtration }+ \\
\text { differential } \\
\text { ultracentrifugation }\end{array}$ & Mouse & Allo & Mouse & $2 \mu \mathrm{g} / \mathrm{g}$ & Intravenous & - Cardioprotective effect & (129) \\
\hline $\begin{array}{l}\text { Myocardial } \\
\text { ischemia/ } \\
\text { reperfusion } \\
\text { injury }\end{array}$ & $\begin{array}{l}\text { Bone } \\
\text { marrow }\end{array}$ & Exosomes & Exo(GATA-4) & $\begin{array}{l}\text { ExoQuick-TC } \\
\text { precipitation }\end{array}$ & Rat & Allo & Rat & $\begin{array}{l}\text { from } 4 \times 10^{6} \\
\text { MSCs }\end{array}$ & Intracardiac & $\begin{array}{l}\text {-Restoring of cardiac contractile function and } \\
\text { reduction of infarct size }\end{array}$ & $(145)$ \\
\hline $\begin{array}{l}\text { Myocardial } \\
\text { ischemia/ } \\
\text { reperfusion } \\
\text { injury }\end{array}$ & $\begin{array}{l}\text { Bone } \\
\text { marrow }\end{array}$ & $\begin{array}{l}\text { Extracellular } \\
\text { vesicles }\end{array}$ & No & $\begin{array}{l}\text { Differential } \\
\text { ultracentrifugation }\end{array}$ & Human & Xeno & Rat & $\begin{array}{l}80 \mu \mathrm{g}, \text { from } 2 \times \\
10^{6} \mathrm{MSCs}\end{array}$ & Intracardiac & $\begin{array}{l}\text {-Enhancement of blood flow recovery } \\
\text {-Reduction of infarct size } \\
\text {-Preservation of cardiac systolic and diastolic } \\
\text { performance }\end{array}$ & $(146)$ \\
\hline $\begin{array}{l}\text { Myocardial } \\
\text { infarction }\end{array}$ & Myocardium & Exosomes & No & PEG precipitation & Mouse & Allo & Mouse & $50 \mu \mathrm{g}$ & Intracardiac & $\begin{array}{l}\text {-Enhancement of cardiac } \\
\text { - Increase of cardiomyocyte proliferation } \\
\text { angiogenesis } \\
\text {-Preservation of heart function }\end{array}$ & $(147)$ \\
\hline
\end{tabular}




\begin{tabular}{|c|c|c|c|c|c|c|c|c|c|c|c|}
\hline Disease & $\begin{array}{l}\text { MSC-EVs' } \\
\text { source }\end{array}$ & $\begin{array}{l}\text { MSC-EVs' } \\
\text { type }\end{array}$ & $\begin{array}{l}\text { MSC-EVs' } \\
\text { modification }\end{array}$ & $\begin{array}{l}\text { MSC-EVs' } \\
\text { isolation } \\
\text { procedure }\end{array}$ & Donor & Compatibility & Host & $\begin{array}{l}\text { MSC-EVs' } \\
\text { dose }\end{array}$ & $\begin{array}{l}\text { Administration } \\
\text { route }\end{array}$ & Main effect & Ref.Nr \\
\hline $\begin{array}{l}\text { Myocardial } \\
\text { infarction }\end{array}$ & $\begin{array}{l}\text { Bone } \\
\text { marrow }\end{array}$ & Exosomes & Exo(CR4) & $\begin{array}{l}\text { ExoQuick-TC } \\
\text { precipitation }\end{array}$ & Rat & Allo & Rat & $N Q$ & Intracardiac & $\begin{array}{l}\text {-Increase of angiogenesis } \\
\text {-Reduction of infarct size } \\
\text {-Improvement of cardiac remodeling }\end{array}$ & (148) \\
\hline $\begin{array}{l}\text { Myocardial } \\
\text { infarction }\end{array}$ & $\begin{array}{l}\text { Bone } \\
\text { marrow }\end{array}$ & Exosomes & No & $\begin{array}{l}\text { Differential } \\
\text { ultracentrifugation }\end{array}$ & Human & Xeno & Mouse & $4 \mu \mathrm{g}$ & Subcutaneous & - Pro-angiogenic effects & (149) \\
\hline $\begin{array}{l}\text { Traumatic brain } \\
\text { injury }\end{array}$ & $\begin{array}{l}\text { Bone } \\
\text { marrow }\end{array}$ & Secretome & No & $\begin{array}{l}\text { Ultrafiltration+ } \\
\text { heparin-agarose } \\
\text { column }\end{array}$ & Human & Xeno & Rat & $500 \mu g$ & Intravenous & $\begin{array}{l}\text {-Attenuation of motor deficits and cerebral } \\
\text { infarction } \\
\text {-Reduction of neuronal loss and apoptosis } \\
\text {-Increase of VEGF-positive cells in the ischemic } \\
\text { cortex } \\
\text {-Functional outcome improvement }\end{array}$ & (153) \\
\hline $\begin{array}{l}\text { Traumatic brain } \\
\text { injury }\end{array}$ & $\begin{array}{l}\text { Bone } \\
\text { marrow }\end{array}$ & Exosomes & No & ExoQuick-TC kit & Rat & Allo & Rat & $100 \mu \mathrm{g}$ & Intravenous & $\begin{array}{l}\text {-Improvement of functional recovery } \\
\text { - Promotion of endogenous angiogenesis and } \\
\text { neurogenesis } \\
\text {-Reduction of inflammation }\end{array}$ & $(154)$ \\
\hline - & $\begin{array}{l}\text { Menstrual } \\
\text { fluid, } \\
\text { chorion, } \\
\text { bone } \\
\text { marrow, } \\
\text { umbilical } \\
\text { cord }\end{array}$ & $\begin{array}{l}\text { Exosomes } \\
\text { Extracellular } \\
\text { vesicles }\end{array}$ & No & $\begin{array}{l}\text { Differential } \\
\text { ultracentrifugation }\end{array}$ & Human & Xeno & $\begin{array}{l}\text { Rat, } \\
\text { Mouse }\end{array}$ & $3 \mu \mathrm{g}$ & - & $\begin{array}{l}\text { - Growth-stimulating effects of exosomes on } \\
\text { longest neurite in cortical neurons and neurite } \\
\text { outgrowth in dorsal root ganglia neurons }\end{array}$ & (155) \\
\hline Stroke & $\begin{array}{l}\text { Bone } \\
\text { marrow }\end{array}$ & Exosomes & $\begin{array}{l}\text { No, } \\
\text { miR-133b+ Exo }\end{array}$ & $\begin{array}{l}\text { Filtration }+ \\
\text { differential } \\
\text { ultracentrifugation }\end{array}$ & Rat & Allo & Rat & $\begin{array}{l}\text { from } 1 \times 10^{7} \\
\text { MSCs }\end{array}$ & Intravenous & $\begin{array}{l}\text { - Improvement of neurite remodelling } \\
\text {-Improvement of functional recovery }\end{array}$ & $(156)$ \\
\hline Stroke & $\begin{array}{l}\text { Bone } \\
\text { marrow }\end{array}$ & Exosomes & No & $\begin{array}{l}\text { Differential } \\
\text { ultracentrifugation }\end{array}$ & Rat & Allo & Rat & - & - & $\begin{array}{l}\text { - Increase of the neurite branch number and total } \\
\text { neurite length }\end{array}$ & $(157)$ \\
\hline $\begin{array}{l}\text { Transient global } \\
\text { Ischemia }\end{array}$ & $\begin{array}{l}\text { Bone } \\
\text { marrow, } \\
\text { adipose } \\
\text { tissue }\end{array}$ & $\begin{array}{l}\text { Extracellular } \\
\text { vesicles }\end{array}$ & No & ExoQuick-TC kit & Mouse & Allo & Mouse & $200 \mu \mathrm{g}$ & Intracerebral & $\begin{array}{l}\text { - Restoration of impaired basal synaptic } \\
\text { transmission and synaptic plasticity - } \\
\text { improvement of spatial learning and memory }\end{array}$ & (158) \\
\hline $\begin{array}{l}\text { Traumatic brain } \\
\text { injury }\end{array}$ & $\begin{array}{l}\text { Bone } \\
\text { marrow }\end{array}$ & $\begin{array}{l}\text { Extracellular } \\
\text { vesicles }\end{array}$ & No & $\begin{array}{l}\text { Scalable } \\
\text { chromatography }\end{array}$ & Human & Xeno & Mouse & $30 \mu \mathrm{g}$ & intravenous & $\begin{array}{l}\text { - suppression of neuroinflammation } \\
\text { - rescue of pattern separation and spatial learning } \\
\text { impairments }\end{array}$ & (159) \\
\hline $\begin{array}{l}\text { Traumatic brain } \\
\text { injury }\end{array}$ & $\begin{array}{l}\text { Bone } \\
\text { marrow }\end{array}$ & Exosomes & No & ExoQuick-TC kit & Human & Xeno & Rat & $\begin{array}{l}100 \mu \mathrm{g} \\
3 \times 10^{9} \\
\text { particles }\end{array}$ & Intravenous & $\begin{array}{l}\text { - Improvement of functional outcome } \\
\text {-Promotion of endogenous angiogenesis and } \\
\text { neurogenesis -reduction of neuroinflammation } \\
\text { - Enhancement of spatial learning }\end{array}$ & $(160)$ \\
\hline Stroke & $\begin{array}{l}\text { Bone } \\
\text { marrow }\end{array}$ & $\begin{array}{l}\text { Extracellular } \\
\text { vesicles }\end{array}$ & No & $\begin{array}{l}\text { PEG precipitation } \\
+ \\
+ \\
\text { ultracentrifugation }\end{array}$ & Human & Xeno & Mouse & $\begin{array}{l}\text { from } 2 \times 10^{6} \\
\text { MSCs }\end{array}$ & Intravenous & $\begin{array}{l}\text { - Improvement of neurological impairment } \\
\text {-Long-term neuroprotection } \\
\text { - Enhanced angioneurogenesis } \\
\text { - Attenuation of postischemic } \\
\text { immunosuppression in the peripheral blood }\end{array}$ & (161) \\
\hline Brain injury & $\begin{array}{l}\text { Bone } \\
\text { marrow }\end{array}$ & $\begin{array}{l}\text { Extracellular } \\
\text { vesicles }\end{array}$ & No & $\begin{array}{l}\text { PEG precipitation } \\
+ \\
\text { ultracentrifugation }\end{array}$ & Human & Xeno & Rat & $\begin{array}{l}\text { from } 1 \times 10^{8} \\
\text { MSCs } / \mathrm{kg}\end{array}$ & Intraperitoneal & $\begin{array}{l}\text { - Prevention of neuronal cell death } \\
\text {-Restoration of white matter microstructure }\end{array}$ & (162) \\
\hline
\end{tabular}




\begin{tabular}{|c|c|c|c|c|c|c|c|c|c|c|c|}
\hline Disease & $\begin{array}{l}\text { MSC-EVs' } \\
\text { source }\end{array}$ & $\begin{array}{l}\text { MSC-EVs' } \\
\text { type }\end{array}$ & $\begin{array}{l}\text { MSC-EVs' } \\
\text { modification }\end{array}$ & $\begin{array}{l}\text { MSC-EVs' } \\
\text { isolation } \\
\text { procedure }\end{array}$ & Donor & Compatibility & Host & $\begin{array}{l}\text { MSC-EVs' } \\
\text { dose }\end{array}$ & $\begin{array}{l}\text { Administration } \\
\text { route }\end{array}$ & Main effect & Ref.Nr \\
\hline & & & & & & & & & & $\begin{array}{l}\text {-Reduction of gliosis } \\
\text {-Improvement of long-lasting cognitive functions }\end{array}$ & \\
\hline Stroke & $\begin{array}{l}\text { Adipose } \\
\text { tissue }\end{array}$ & $\begin{array}{l}\text { Extracellular } \\
\text { vesicles }\end{array}$ & No & $\begin{array}{l}\text { miRCURYTM } \\
\text { exosome Isolation } \\
\text { kit }\end{array}$ & Rat & Allo & Rat & $100 \mu \mathrm{g}$ & Intravenous & $\begin{array}{l}\text { - Improvement of functional recovery, fiber tract } \\
\text { integrity, axonal sprouting and white matter repair } \\
\text { markers }\end{array}$ & (163) \\
\hline $\begin{array}{l}\text { Focal brain } \\
\text { injury }\end{array}$ & $\begin{array}{l}\text { Bone } \\
\text { marrow }\end{array}$ & $\begin{array}{l}\text { Extracellular } \\
\text { vesicles }\end{array}$ & No & $\begin{array}{l}\text { Differential } \\
\text { ultracentrifugation }\end{array}$ & Human & Xeno & Rat & $\begin{array}{l}1.3 \times 10^{9} \\
\text { particles } \\
\text { from } \\
5 \times 10^{6} \mathrm{MSCs}\end{array}$ & Intra-arterial & $\begin{array}{l}\text { - Decrease of cell activation i.e., astrocytes, } \\
\text { microglia, and infiltration of leucocytes, including } \\
\text { T cytotoxic cells } \\
\text { - Decrease of pro-inflammatory cytokines and } \\
\text { chemokines }\end{array}$ & $(164)$ \\
\hline $\begin{array}{l}\text { Fetal brain } \\
\text { ischemia }\end{array}$ & $\begin{array}{l}\text { Bone } \\
\text { marrow }\end{array}$ & $\begin{array}{l}\text { Extracellular } \\
\text { vesicles }\end{array}$ & No & PEG precipitation & Human & Xeno & Sheep & $\begin{array}{l}\text { from } 4.0 \times 10^{7} \\
\text { MSCs }\end{array}$ & Intravenous & $\begin{array}{l}\text { - Reduction of the total number and duration of } \\
\text { seizures } \\
\text { - Preservation of baroreceptor reflex sensitivity } \\
\text { - Tendency to prevent hypomyelination }\end{array}$ & (165) \\
\hline $\begin{array}{l}\text { Spinal cord } \\
\text { injury }\end{array}$ & $\begin{array}{l}\text { Umbilical } \\
\text { cord }\end{array}$ & Exosomes & No & $\begin{array}{l}\text { Differential } \\
\text { ultracentrifugation }\end{array}$ & Human & Xeno & Mouse & $\begin{array}{l}20 \mu \mathrm{g} \\
200 \mu \mathrm{g}\end{array}$ & Intravenous & $\begin{array}{l}\text { - Improvement of functional recovery } \\
\text { - Down-regulation of the inflammatory cytokines }\end{array}$ & $(166)$ \\
\hline $\begin{array}{l}\text { Spinal cord } \\
\text { injury }\end{array}$ & $\begin{array}{l}\text { Bone } \\
\text { marrow }\end{array}$ & $\begin{array}{l}\text { Extracellular } \\
\text { vesicles }\end{array}$ & No & $\begin{array}{l}\text { Differential } \\
\text { ultracentrifugation }\end{array}$ & Rat & Allo & Rat & $\begin{array}{l}40 \mu \mathrm{g} \\
\text { from } \\
1 \times 10^{6} \mathrm{MSCs}\end{array}$ & Intravenous & $\begin{array}{l}\text { - Reduction of brain cell death } \\
\text { - Enhancement of neuronal survival and } \\
\text { regeneration } \\
\text { - Improvement of motor function }\end{array}$ & (167) \\
\hline $\begin{array}{l}\text { Spinal Cord } \\
\text { Injury }\end{array}$ & $\begin{array}{l}\text { Bone } \\
\text { marrow }\end{array}$ & $\begin{array}{l}\text { Extracellular } \\
\text { vesicles }\end{array}$ & $\begin{array}{l}\text { No, } \\
\text { from MSCs } \\
\text { stimulated with } \\
\text { TNF- } \alpha+\text { IFN- } \gamma\end{array}$ & $\begin{array}{l}\text { Sequential } \\
\text { filtration }\end{array}$ & Human & Xeno & Rat & $\begin{array}{l}1 \times 10^{9} \\
\text { particles } / \mathrm{ml}\end{array}$ & Intravenous & $\begin{array}{l}\text { - Attenuation of neuroinflammation } \\
\text { - Improvement of functional recovery }\end{array}$ & (168) \\
\hline Hepatic Failure & $\begin{array}{l}\text { Bone } \\
\text { marrow }\end{array}$ & $\begin{array}{l}\text { Extracellular } \\
\text { vesicles }\end{array}$ & No & $\begin{array}{l}\text { Differential } \\
\text { ultracentrifugation }\end{array}$ & $\begin{array}{l}\text { Mouse } \\
\text { Human }\end{array}$ & $\begin{array}{l}\text { Allo } \\
\text { Xeno }\end{array}$ & Mouse & $\begin{array}{l}2 \times 10^{8} \text { to } \\
2 \times 10^{10} \\
\text { particles }\end{array}$ & $\begin{array}{l}\text { Intravenous, } \\
\text { Intraperitoneal }\end{array}$ & $\begin{array}{l}\text { - Reduction of hepatic injury } \\
\text { - Modulation of cytokine expression } \\
\text { - Increase of survival }\end{array}$ & (169) \\
\hline Liver injury & $\begin{array}{l}\text { Bone } \\
\text { marrow }\end{array}$ & $\begin{array}{l}\text { Exosomes, } \\
\text { Secretome }\end{array}$ & No & $\begin{array}{l}\text { Differential } \\
\text { ultracentrifugation }\end{array}$ & Rat & Allo & Rat & $50 \mu \mathrm{g}$ & Intravenous & - Improvement of liver regeneration & (171) \\
\hline $\begin{array}{l}\text { Hepatic } \\
\text { ischemia } \\
\text { reperfusion } \\
\text { injury }\end{array}$ & $\begin{array}{l}\text { Bone } \\
\text { marrow }\end{array}$ & $\begin{array}{l}\text { Extracellular } \\
\text { vesicles }\end{array}$ & No & $\begin{array}{l}\text { Differential } \\
\text { ultracentrifugation } \\
+ \text { filtration }\end{array}$ & Human & Xeno & Mouse & $1 \times 10^{9}$ particles & Intravenous & $\begin{array}{l}\text {-Reduction of hepatic necrosis } \\
\text { - Increase of the amount of hepatocytes } \\
\text { - Repression of the transcription of inflammation- } \\
\text { associated genes } \\
\text { - Attenuation of liver damage and improvement of } \\
\text { organ regeneration }\end{array}$ & (171) \\
\hline Liver injury & $\begin{array}{l}\text { Bone } \\
\text { marrow }\end{array}$ & Exosomes & No & $\begin{array}{l}\text { Differential } \\
\text { ultracentrifugation }\end{array}$ & Mouse & Allo & Mouse & $10 \mu \mathrm{g}$ & Intravenous & $\begin{array}{l}\text { - Decreases in ALT, liver necrotic areas, and the } \\
\text { extent of apoptosis } \\
\text { - Increase in the cell proliferation } \\
\text { - Enhancement of anti-inflammatory cytokines } \\
\text { and T regulatory cells }\end{array}$ & $(172)$ \\
\hline $\begin{array}{l}\text { Acute kidney } \\
\text { injury }\end{array}$ & $\begin{array}{l}\text { Bone } \\
\text { marrow }\end{array}$ & Microvesicles & No & $\begin{array}{l}\text { Differential } \\
\text { ultracentrifugation }\end{array}$ & Human & Xeno & Mouse & $15 \mu \mathrm{g}$ & Intravenous & $\begin{array}{l}\text { - Acceleration of the morphologic and functional } \\
\text { recovery } \\
\text {-Induction of proliferation of tubular cells }\end{array}$ & (173) \\
\hline $\begin{array}{l}\text { Acute and } \\
\text { chronic kidney } \\
\text { injury }\end{array}$ & $\begin{array}{l}\text { Bone } \\
\text { marrow }\end{array}$ & Microvesicles & No & $\begin{array}{l}\text { Differential } \\
\text { ultracentrifugation }\end{array}$ & Human & Xeno & Rat & $30 \mu \mathrm{g}$ & Intravenous & $\begin{array}{l}\text { - Protection from acute kidney injury } \\
\text { - Inhibition of apoptosis } \\
\text { - Stimulation of tubular epithelial cell proliferation }\end{array}$ & (174) \\
\hline
\end{tabular}




\begin{tabular}{|c|c|c|c|c|c|c|c|c|c|c|c|}
\hline Disease & $\begin{array}{l}\text { MSC-EVs' } \\
\text { source }\end{array}$ & $\begin{array}{l}\text { MSC-EVs' } \\
\text { type }\end{array}$ & $\begin{array}{l}\text { MSC-EVs' } \\
\text { modification }\end{array}$ & $\begin{array}{l}\text { MSC-EVs' } \\
\text { isolation } \\
\text { procedure }\end{array}$ & Donor & Compatibility & Host & $\begin{array}{l}\text { MSC-EVs' } \\
\text { dose }\end{array}$ & $\begin{array}{l}\text { Administration } \\
\text { route }\end{array}$ & Main effect & Ref.Nr \\
\hline & & & & & & & & & & $\begin{array}{l}\text { - Reduction of the impairment of renal function } \\
\text { - Protection from later chronic kidney disease }\end{array}$ & \\
\hline $\begin{array}{l}\text { Renal tubular } \\
\text { cells injury }\end{array}$ & $\begin{array}{l}\text { Bone } \\
\text { marrow }\end{array}$ & $\begin{array}{l}\text { Extracellular } \\
\text { vesicles }\end{array}$ & No & $\begin{array}{l}\text { Differential } \\
\text { ultracentrifugation }\end{array}$ & Human & Allo & Human & $3 \times 10^{9}$ particles & - & $\begin{array}{l}\text { - miRNAs of EVs are involved in the repair and } \\
\text { recovery process in proximal tubular epithelial } \\
\text { cells }\end{array}$ & (175) \\
\hline $\begin{array}{l}\text { Kidney } \\
\text { ischemia } \\
\text { reperfusion } \\
\text { injury }\end{array}$ & $\begin{array}{l}\text { Umbilical } \\
\text { cord }\end{array}$ & $\begin{array}{l}\text { Extracellular } \\
\text { vesicles }\end{array}$ & No & $\begin{array}{l}\text { Differential } \\
\text { ultracentrifugation }\end{array}$ & Human & Xeno & Rat & $\begin{array}{l}100 \mu g \\
\text { from } 5 \times 10^{5} \\
\text { MSCs }\end{array}$ & Intravenous & $\begin{array}{l}\text { - Reduction of cell apoptosis } \\
\text { - Enhancement of cell proliferation } \\
\text { - Increase of capillary vessel density } \\
\text {-Reduction of renal fibrosis }\end{array}$ & (176) \\
\hline $\begin{array}{l}\text { Acute kidney } \\
\text { injury }\end{array}$ & $\begin{array}{l}\text { Umbilical } \\
\text { cord }\end{array}$ & Exosomes & No & $\begin{array}{l}\text { Differential } \\
\text { ultracentrifugation }\end{array}$ & Human & Xeno & Rat & $200 \mu \mathrm{g}$ & Intra-renal & $\begin{array}{l}\text { - Prevention from nephrotoxicity by activation of } \\
\text { autophagy }\end{array}$ & (177) \\
\hline $\begin{array}{l}\text { Acute kidney } \\
\text { injury }\end{array}$ & $\begin{array}{l}\text { Bone } \\
\text { marrow }\end{array}$ & $\begin{array}{l}\text { Extracellular } \\
\text { vesicles }\end{array}$ & $\begin{array}{l}\text { No } \\
\text { EVs with } \\
\text { downregulation } \\
\text { of microRNA }\end{array}$ & $\begin{array}{l}\text { Differential } \\
\text { ultracentrifugation }\end{array}$ & Human & Xeno & Mouse & $\begin{array}{l}2.2 \times 10^{8} \\
\text { particles } \\
\text { from } 7.5 \times 10^{4} \\
\text { MSCs }\end{array}$ & Intravenous & $\begin{array}{l}\text { - Induction of morphologic and functional } \\
\text { recovery by wild-type EVs not by EVs with } \\
\text { downregulation of microRNA } \\
\text { - microRNA depletion reduced intrinsic } \\
\text { regenerative potential of EVs }\end{array}$ & (178) \\
\hline $\begin{array}{l}\text { Unilateral } \\
\text { renovascular } \\
\text { disease }\end{array}$ & $\begin{array}{l}\text { Adipose } \\
\text { tissue }\end{array}$ & $\begin{array}{l}\text { Extracellular } \\
\text { vesicles }\end{array}$ & No & $\begin{array}{l}\text { Differential } \\
\text { ultracentrifugation }\end{array}$ & Pig & Auto & Pig & $\begin{array}{l}\text { from } 10 \times 10^{6} \\
\text { MSCs }\end{array}$ & Intra-renal & $\begin{array}{l}\text { - Bearing pro-angiogenic properties restoring the } \\
\text { renal microcirculation and in turn hemodynamics } \\
\text { and functions }\end{array}$ & (179) \\
\hline $\begin{array}{l}\text { Renal ischemia- } \\
\text { reperfusion } \\
\text { injury }\end{array}$ & $\begin{array}{l}\text { Umbilical } \\
\text { cord }\end{array}$ & Microvesicles & No & $\begin{array}{l}\text { Differential } \\
\text { ultracentrifugation }\end{array}$ & Human & Xeno & Rat & $\begin{array}{l}100 \mu \mathrm{g} \\
\text { from } 5 \times 10^{5} \\
\text { MSCs }\end{array}$ & Intravenous & $\begin{array}{l}\text { - Mitigation of renal cell apoptosis } \\
\text { - Enhancement of proliferation } \\
\text { - Alleviation of inflammation } \\
\text { - Suppression of the expression of chemokines } \\
\text { and decrease the number of macrophages in the } \\
\text { kidney } \\
\text { - Improvement of renal function and abrogation of } \\
\text { renal fibrosis }\end{array}$ & (180) \\
\hline $\begin{array}{l}\text { Acute lung } \\
\text { injury }\end{array}$ & $\begin{array}{l}\text { Bone } \\
\text { marrow }\end{array}$ & Microvesicles & $\begin{array}{l}\text { Ang-1 mRNA } \\
\text { deficient MVs }\end{array}$ & $\begin{array}{l}\text { Differential } \\
\text { ultracentrifugation }\end{array}$ & Human & Xeno & Mouse & $\begin{array}{l}\text { from } 1 \times 10^{6} \\
\text { MSCs }\end{array}$ & Intratracheal & $\begin{array}{l}\text { - Deteriorative lung inflammation and a failure to } \\
\text { restore pulmonary capillary permeability after } \\
\text { Ang-1 mRNA deficient MVs injection }\end{array}$ & (181) \\
\hline $\begin{array}{l}\text { Acute lung } \\
\text { injury }\end{array}$ & $\begin{array}{l}\text { Bone } \\
\text { marrow }\end{array}$ & Microvesicles & No & $\begin{array}{l}\text { Differential } \\
\text { ultracentrifugation }\end{array}$ & Human & Xeno & Mouse & $\begin{array}{l}30.9 \pm 17.0 \mu \mathrm{g} \\
\text { from } 3 \times 10^{6} \\
\text { MSCs }\end{array}$ & Intratracheal & $\begin{array}{l}\text { - Reduction in pulmonary edema and lung protein } \\
\text { permeability } \\
\text { - Reduction in inflammation }\end{array}$ & (182) \\
\hline $\begin{array}{l}\text { Acute lung } \\
\text { injury }\end{array}$ & $\begin{array}{l}\text { Bone } \\
\text { marrow }\end{array}$ & $\begin{array}{l}\text { Extracellular } \\
\text { vesicles }\end{array}$ & No & $\begin{array}{l}\text { Differential } \\
\text { ultracentrifugation }\end{array}$ & Pig & Allo & Pig & $80 \mu \mathrm{g} / \mathrm{kg}$ & Intratracheal & $\begin{array}{l}\text { - Reduction of virus shedding, influenza virus } \\
\text { replication, production of proinflammatory } \\
\text { cytokines - Alleviation of influenza virus-induced } \\
\text { lung lesions }\end{array}$ & (183) \\
\hline $\begin{array}{l}\text { Pulmonary } \\
\text { fibrosis }\end{array}$ & $\begin{array}{l}\text { Bone } \\
\text { marrow }\end{array}$ & $\begin{array}{l}\text { Extracellular } \\
\text { vesicles }\end{array}$ & No & Density flotation & Human & Xeno & Mouse & $\begin{array}{l}8.6 \times 10^{8} \\
\text { particles } \\
\text { from } 5 \times 10^{6} \\
\text { MSCs }\end{array}$ & $\begin{array}{l}\text { Intravenous, } \\
\text { Intracardiac }\end{array}$ & $\begin{array}{l}\text { - Prevention and reversion of bleomycin- } \\
\text { induced pulmonary fibrosis } \\
\text { - Promotion of an immunoregulatory, anti- } \\
\text { inflammatory monocyte phenotype }\end{array}$ & (184) \\
\hline $\begin{array}{l}\text { Acute } \\
\text { respiratory } \\
\text { distress } \\
\text { syndrome }\end{array}$ & $\begin{array}{l}\text { Bone } \\
\text { marrow }\end{array}$ & $\begin{array}{l}\text { Extracellular } \\
\text { vesicles }\end{array}$ & $\begin{array}{l}\text { EV-treated } \\
\text { alveolar } \\
\text { macrophages }\end{array}$ & $\begin{array}{l}\text { Differential } \\
\text { ultracentrifugation }\end{array}$ & Human & Xeno & Mouse & $\begin{array}{l}\text { from } 7.5 \times 10^{6} \\
\text { cells } / \mathrm{ml}\end{array}$ & Intranasal & $\begin{array}{l}\text { - Reduction of inflammation } \\
\text { - Amelioration of lung injury }\end{array}$ & (185) \\
\hline
\end{tabular}




\begin{tabular}{|c|c|c|c|c|c|c|c|c|c|c|c|}
\hline Disease & $\begin{array}{l}\text { MSC-EVs' } \\
\text { source }\end{array}$ & $\begin{array}{l}\text { MSC-EVs' } \\
\text { type }\end{array}$ & $\begin{array}{l}\text { MSC-EVs' } \\
\text { modification }\end{array}$ & $\begin{array}{l}\text { MSC-EVs' } \\
\text { isolation } \\
\text { procedure }\end{array}$ & Donor & Compatibility & Host & $\begin{array}{l}\text { MSC-EVs' } \\
\text { dose }\end{array}$ & $\begin{array}{l}\text { Administration } \\
\text { route }\end{array}$ & Main effect & Ref.Nr \\
\hline $\begin{array}{l}\text { Lung } \\
\text { pneumonia }\end{array}$ & $\begin{array}{l}\text { Bone } \\
\text { marrow }\end{array}$ & Microvesicles & No & $\begin{array}{l}\text { Differential } \\
\text { ultracentrifugation }\end{array}$ & Human & Allo & Human & $\begin{array}{l}\text { from } 2 \times 10^{7} \text { or } \\
4 \times 10^{7} \mathrm{MSCs}\end{array}$ & Intravenous & $\begin{array}{l}\text {-Increase of the alveolar fluid clearance } \\
\text { - Reduction of the protein permeability } \\
\text {-Lower bacterial load in the injured alveolus } \\
\text { - Enhancement of the antimicrobial activity of } \\
\text { MVs after pretreatment with polyinosinic: } \\
\text { polycytidylic acid }\end{array}$ & (186) \\
\hline Wound healing & $\begin{array}{l}\text { Umbilical } \\
\text { cord }\end{array}$ & Exosomes & No & $\begin{array}{l}\text { Differential } \\
\text { ultracentrifugation } \\
+ \text { filtration }\end{array}$ & Human & Xeno & Rat & $200 \mu g$ & Subcutaneous & $\begin{array}{l}\text { - Acceleration of re-epithelialization } \\
\text { - Reduction of heat stress-induced apoptosis }\end{array}$ & $(187)$ \\
\hline Wound healing & $\begin{array}{l}\text { Umbilical } \\
\text { cord }\end{array}$ & Exosomes & No & $\begin{array}{l}\text { Differential } \\
\text { ultracentrifugation }\end{array}$ & Human & Xeno & Rat & $200 \mu \mathrm{g}$ & Subcutaneous & - Promotion of wound healing and angiogenesis & (188) \\
\hline Fracture healing & $\begin{array}{l}\text { Bone } \\
\text { marrow }\end{array}$ & Exosomes & No & $\begin{array}{l}\text { Differential } \\
\text { ultracentrifugation }\end{array}$ & Human & Xeno & Mouse & - & Local & - Facilitation of the acceleration of fracture healing & (189) \\
\hline $\begin{array}{l}\text { Osteochondral } \\
\text { defects }\end{array}$ & Embryo & Exosomes & No & $\begin{array}{l}\text { HPLC } \\
\text { fractionation }\end{array}$ & Human & Xeno & Rat & $100 \mu \mathrm{g}$ & Intra-articular & $\begin{array}{l}\text { - Enhancement of gross appearance and } \\
\text { improvement of histological scores } \\
\text { - Complete restoration of cartilage and } \\
\text { subchondral bone }\end{array}$ & (190) \\
\hline $\begin{array}{l}\text { Calvarial } \\
\text { defects }\end{array}$ & $\begin{array}{l}\text { Adipose } \\
\text { tissue }\end{array}$ & Exosomes & $\begin{array}{l}\text { Immobilized on } \\
\text { the } \\
\text { polydopamine- } \\
\text { coating PLGA } \\
\text { scaffolds }\end{array}$ & $\begin{array}{l}\text { Differential } \\
\text { ultracentrifugation } \\
+ \text { filtration }\end{array}$ & Human & Xeno & Mouse & $25 \mu \mathrm{g} / \mathrm{ml}$ & Local & $\begin{array}{l}\text { - Enhancement of bone regeneration } \\
\text { - Osteoinductive effects and capacities of } \\
\text { promoting MSCs migration and homing in the } \\
\text { newly formed bone tissue }\end{array}$ & (191) \\
\hline $\begin{array}{l}\text { Calvarial } \\
\text { defects }\end{array}$ & $\begin{array}{l}\text { Bone } \\
\text { marrow }\end{array}$ & $\begin{array}{l}\text { Extracellular } \\
\text { vesicles }\end{array}$ & $\begin{array}{l}\text { EVs in HyStem- } \\
\text { HP hydrogel }\end{array}$ & $\begin{array}{l}\text { Differential } \\
\text { ultracentrifugation } \\
\text { and ultrafiltration }\end{array}$ & Human & Xeno & Rat & $100 \mu \mathrm{g}$ & Local & $\begin{array}{l}\text { - More bone formation in the critical-size calvarial } \\
\text { bone defects }\end{array}$ & (192) \\
\hline Colitis & $\begin{array}{l}\text { Bone } \\
\text { marrow }\end{array}$ & $\begin{array}{l}\text { Extracellular } \\
\text { vesicles }\end{array}$ & No & $\begin{array}{l}\text { Differential } \\
\text { ultracentrifugation }\end{array}$ & Rat & Allo & Rat & $50,100,200 \mu \mathrm{g}$ & Intravenous & $\begin{array}{l}\text { - Attenuation of the severity of colitis } \\
\text { - Down regulation of pro-inflammatory cytokines } \\
\text { - Modulation of anti-oxidant/oxidant balance } \\
\text { - Moderation of the occurrence of apoptosis }\end{array}$ & (193) \\
\hline $\begin{array}{l}\text { Inflammatory } \\
\text { bowel disease }\end{array}$ & $\begin{array}{l}\text { Umbilical } \\
\text { cord }\end{array}$ & Exosomes & No & $\begin{array}{l}\text { Density gradient + } \\
\text { Differential } \\
\text { ultracentrifugation }\end{array}$ & Human & Xeno & Mouse & $400 \mu \mathrm{g}$ & Intravenous & $\begin{array}{l}\text { - Relieved the severity of the disease } \\
\text { - Increase of IL-10 } \\
\text { - Decrease of pro-inflammatory cytokines } \\
\text { - Decrease of the infiltration of macrophages into } \\
\text { the colon tissues }\end{array}$ & (194) \\
\hline $\begin{array}{l}\text { Sepsis } \\
\text { syndrome }\end{array}$ & $\begin{array}{l}\text { Adipose } \\
\text { tissue }\end{array}$ & Exosomes & $\begin{array}{l}\text { No, apoptotic- } \\
\text { exosomes }\end{array}$ & $\begin{array}{l}\text { Differential } \\
\text { ultracentrifugation } \\
+ \text { filtration }\end{array}$ & Rat & Allo & Rat & $100 \mu g$ & Intravenous & $\begin{array}{l}\text { - Improvement of survival and suppression of the } \\
\text { inflammatory reactions by healthy exosomes } \\
\text { superior to apoptotic exosomes }\end{array}$ & (195) \\
\hline $\begin{array}{l}\text { Graft-versus- } \\
\text { host disease }\end{array}$ & $\begin{array}{l}\text { Bone } \\
\text { marrow }\end{array}$ & Exosomes & No & $\begin{array}{l}\text { Differential } \\
\text { ultracentrifugation } \\
\text { + filtration }\end{array}$ & Human & Xeno & Mouse & $100 \mu \mathrm{g}$ & Intravenous & $\begin{array}{l}\text { - Prolongation of the survival and diminishment of } \\
\text { the clinical and pathological scores - amelioration } \\
\text { of the fibrosis in the skin, lung, and liver } \\
\text { - Reduction of activation and infiltration into lungs } \\
\text { of CD4+ T cells, inhibition of IL-17-T cells and } \\
\text { induction of IL-10- regulatory cells, reduction of } \\
\text { pro-inflammatory cytokines }\end{array}$ & (196) \\
\hline $\begin{array}{l}\text { Graft-versus- } \\
\text { host disease }\end{array}$ & $\begin{array}{l}\text { Umbilical } \\
\text { cord }\end{array}$ & $\begin{array}{l}\text { Extracellular } \\
\text { vesicles }\end{array}$ & No & $\begin{array}{l}\text { Differential } \\
\text { ultracentrifugation }\end{array}$ & Human & Xeno & Mouse & $200 \mu \mathrm{g}$ & Intravenous & $\begin{array}{l}\text { - Alleviation of the manifestations of aGVHD and } \\
\text { reduction of the mortality }\end{array}$ & (197) \\
\hline
\end{tabular}




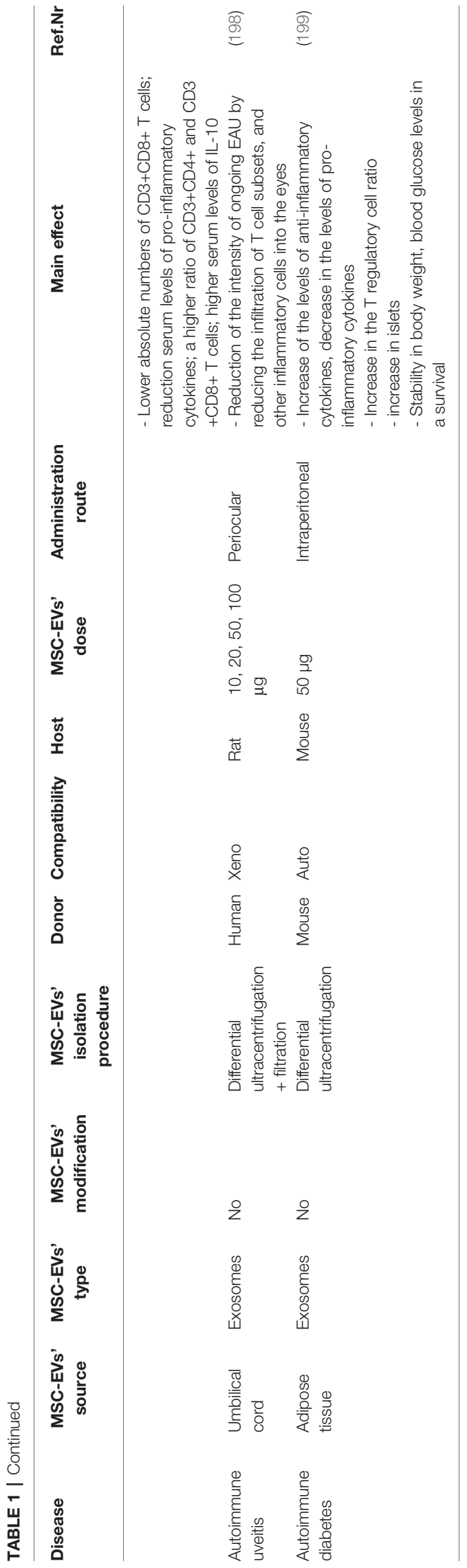

inflammatory cells was observed less often in these bone specimens (203).

MSC-EVs have also been studied in patients with chronic kidney disease (CKD). The trial was conducted by Nassar et al. to assess the safety and therapeutic efficacy of umbilical cord MSC-EVs in ameliorating the progress of chronic kidney disease. Forty CKD patients were enrolled in phase II/III clinical studies. The patients have been divided into two groups, the first group (20 CKD patients) was treated by two doses of MSC-EVs, the first dose injected intravenous (IV) and the second dose administrated intrarenal arteries (IA) one week later. The control group (20 CKD patients) received saline solution infused IV. The therapy was safe, there were any significant adverse effects noticed after the treatment up to one year of studies. Infusion of MSC-EVs ameliorated clinical symptoms and transiently (3-6 months) improved the kidney function, reducing blood urea and serum creatinine while increasing eGRP. Moreover, CKD patients treated with MSC-EVs demonstrated amended inflammatory immune reaction observed by the significant increase of TGF- $\beta 1$ and IL-10 and the decrease in TNF- $\alpha$ level in plasma (204).

To sum up, MSC-EVs seem to be interesting approach to be studied in clinical trials of different diseases especially those accompanied with inflammatory component. There are currently several trials evaluating MSC-EVs reported to Clinicaltrials.gov. Most of them are in recruiting or not yet recruiting status (Table 2). The beneficial effects of MSC-EVs could be enhanced by bioengineering and genetic modifications, stimulation with different growth factors or drug encapsulation. However, there are challenges to optimize MSC-EVs clinical use $(205,206)$. Further research is warranted to establish optimal culture conditions of MSCs, suitable therapeutic doses and administration routs but also the standardized protocols for EVs isolation and storage.

\section{Therapeutic Potential of MSCs and MSC- EVs in COVID-19}

The outbreak of pneumonia in Wuhan, China in the late 2019 led to the detection of a new contagion - severe acute respiratory syndrome coronavirus 2 (SARS-CoV-2), causing coronavirus disease 2019 (COVID-19) (207). The virus has rapidly spread worldwide and has become a global threat unheard of for decades (208). The considerable variation of clinical course of infected people from nearly $50 \%$ being asymptomatic but contagious to $10 \%$ of severe cases and $1 \%$ to $2 \%$ of deaths makes the disease difficult to trace. More importantly, the disease causes the massive burden on the healthcare systems due to rapidly appearing new serious cases. It was early shown that the severity of the disease results not only from the lytic activity of the virus, but also from the dysregulation of the immune system and the abnormal immune response in the form of cytokine storm (209). Moreover, pulmonary fibrotic consequences may follow COVID-19 (210).

Numerous preclinical studies have demonstrated the immunomodulatory and antifibrotic properties of MSCs (211213). Their clinical safety in treating bacterial sepsis and the ability to temporarily reduce the value of anti-inflammatory cytokines in the system have been already confirmed (214, 215). The first case series of patients with COVID-19 indicated the possibility of obtaining therapeutic benefits from the 
TABLE 2 | Clinical trials using MSC-EVs therapy in different disorders.

\begin{tabular}{|c|c|c|c|c|c|}
\hline Study title & $\begin{array}{l}\text { Condition of } \\
\text { disease }\end{array}$ & Intervention treatment & $\begin{array}{c}\text { Trial } \\
\text { Phase }\end{array}$ & Status & Trial ID \\
\hline $\begin{array}{l}\text { A tolerance clinical study on aerosol inhalation of } \\
\text { mesenchymal stem cells exosomes in healthy } \\
\text { volunteers }\end{array}$ & Healthy & $\begin{array}{l}\text { Aerosol inhalation of allogeneic AD MSC-EVs }\left(2 \times 10^{8} \text { or } 4\right. \\
\left.\times 10^{8} \text { or } 8 \times 10^{8} \text { or } 12 \times 10^{8} \text { or } 16 \times 10^{8} \text { or } 20 \times 10^{8}\right)\end{array}$ & $\begin{array}{l}\text { Phase } \\
\text { I }\end{array}$ & Recruiting & $\begin{array}{l}\text { NCT } \\
04313647\end{array}$ \\
\hline $\begin{array}{l}\text { A safety study of IV stem cell-derived extracellular } \\
\text { vesicles (UNEX-42) in preterm neonates at high } \\
\text { risk for BPD }\end{array}$ & $\begin{array}{l}\text { Bronchopulmonary } \\
\text { dysplasia }\end{array}$ & $\begin{array}{l}\text { IV infusion of BM-MSC-EVs ( } 20 \text { or } 60 \text { or } 200 \text { pmol } \\
\text { phospholipids/kg body weight) }\end{array}$ & $\begin{array}{l}\text { Phase } \\
\text { I }\end{array}$ & Recruiting & $\begin{array}{l}\text { NCT } \\
03857841\end{array}$ \\
\hline $\begin{array}{l}\text { A clinical study of mesenchymal stem cell } \\
\text { exosomes nebulizer for the treatment of ARDS }\end{array}$ & $\begin{array}{l}\text { Acute Respiratory } \\
\text { distress syndrome }\end{array}$ & $\begin{array}{l}\text { Aerosol inhalation of allogeneic MSC-EVs }\left(2 \times 10^{8} \text { or } 8 \times\right. \\
\left.10^{8} \text { or } 16 \times 10^{8} \text { particles for } 7 \text { days }\right)\end{array}$ & $\begin{array}{l}\text { Phase } \\
\text { I }\end{array}$ & Recruiting & $\begin{array}{l}\text { NCT } \\
04602104\end{array}$ \\
\hline $\begin{array}{l}\text { A clinical study of allogeneic human adipose- } \\
\text { derived mesenchymal progenitor cell exosomes } \\
\text { (haMPC-Exos) nebulizer for the treatment of } \\
\text { carbapenem-resistant gram-negative bacilli- } \\
\text { induced pulmonary infection }\end{array}$ & $\begin{array}{l}\text { Pulmonary infection } \\
\text { caused by gram- } \\
\text { negative bacilli } \\
\text { resistant to } \\
\text { carbapenems }\end{array}$ & $\begin{array}{l}\text { Aerosol inhalation of MSC-EVs }\left(8 \times 10^{8} \text { or } 16 \times 10^{8}\right. \\
\text { nanovesicles for } 7 \text { days })\end{array}$ & $\begin{array}{l}\text { Phase } \\
\text { I/II }\end{array}$ & Recruiting & $\begin{array}{l}\text { NCT } \\
04544215\end{array}$ \\
\hline $\begin{array}{l}\text { A pilot clinical study on inhalation of mesenchymal } \\
\text { stem cells exosomes treating severe novel } \\
\text { coronavirus pneumonia }\end{array}$ & COVID-19 & $\begin{array}{l}\text { Aerosol inhalation of allogeneic MSC-EVs }\left(2 \times 10^{8}\right. \\
\text { nanovesicles } / 3 \mathrm{ml} \text { for } 5 \text { days })\end{array}$ & $\begin{array}{l}\text { Phase } \\
\text { I }\end{array}$ & $\begin{array}{l}\text { Recruiting } \\
\text { completed }\end{array}$ & $\begin{array}{l}\text { NCT } \\
04276987\end{array}$ \\
\hline $\begin{array}{l}\text { Allogenic mesenchymal stem cell derived exosome } \\
\text { in patients with acute ischemic stroke }\end{array}$ & $\begin{array}{l}\text { Acute ischemic } \\
\text { stroke }\end{array}$ & $\begin{array}{l}\text { Stereotactic intra-parenchymal infusion of allogeneic MSC- } \\
\text { EVs enriched by miR-124 }\end{array}$ & $\begin{array}{l}\text { Phase } \\
|/| \mid\end{array}$ & Recruiting & $\begin{array}{l}\text { NCT } \\
03384433\end{array}$ \\
\hline $\begin{array}{l}\text { The safety and the efficacy evaluation of allogenic } \\
\text { adipose MSC-exos in patients With Alzheimer's } \\
\text { disease }\end{array}$ & Alzheimer Disease & $\begin{array}{l}\text { Allogeneic MSC-EVs administered by nasal drip ( } 5 \mu \mathrm{g} \text { or } \\
10 \mu \mathrm{g} \text { or } 20 \mu \mathrm{g} \text { in } 1 \mathrm{ml} \text { twice a week for } 12 \text { weeks) }\end{array}$ & $\begin{array}{l}\text { Phase } \\
|/| \mid\end{array}$ & Recruiting & $\begin{array}{l}\text { NCT } \\
04388982\end{array}$ \\
\hline $\begin{array}{l}\text { Comparative effectiveness of arthroscopy and non- } \\
\text { arthroscopy using mesenchymal stem cell therapy } \\
\text { (MSCs) and conditioned medium for osteoarthritis }\end{array}$ & Osteoarthritis, knee & $\begin{array}{l}\text { Intraarticular injection of UC-MSC-EVs ( } 2 \text { cc/knee and } 2 \\
\text { cc/knee } 4 \text { weeks later) }\end{array}$ & $\begin{array}{l}\text { Phase } \\
\text { I/II }\end{array}$ & Recruiting & $\begin{array}{l}\text { NCT } \\
04314661\end{array}$ \\
\hline $\begin{array}{l}\text { Effects of ASC secretome on human } \\
\text { osteochondral explants }\end{array}$ & Osteoarthritis & $\begin{array}{l}\text { ASC-Esc or ASc conditioned medium applied ex vivo on } \\
\text { osteochondral explants }\end{array}$ & $\begin{array}{l}\text { Phase } \\
\text { I }\end{array}$ & $\begin{array}{l}\text { Not-yet } \\
\text { recruiting }\end{array}$ & $\begin{array}{l}\text { NCT } \\
04223622\end{array}$ \\
\hline MSC Evs in dystrophic epidermolysis bullosa & $\begin{array}{l}\text { Dystrophic } \\
\text { epidermolysis } \\
\text { bullosa }\end{array}$ & $\begin{array}{l}\text { Allogeneic MSC-EVs applicate locally on lesion once a day } \\
\text { for } 60 \text { days }\end{array}$ & $\mathrm{N} / \mathrm{A}$ & $\begin{array}{l}\text { Not-yet } \\
\text { recruiting }\end{array}$ & $\begin{array}{l}\text { NCT } \\
04173650\end{array}$ \\
\hline MSC-exos promote healing of MHs & $\begin{array}{l}\text { Idiopathic macular } \\
\text { hole }\end{array}$ & $\begin{array}{l}\text { UC-MSC-Exosomes ( } 20 \mu \mathrm{g} \text { or } 50 \mu \mathrm{g} \text { in } 10 \mu \mathrm{l} \text { of PBS } \\
\text { dripped into vitreous cavity around } \mathrm{MH} \text { ) }\end{array}$ & $\begin{array}{l}\text { Early } \\
\text { Phase } \\
\text { I }\end{array}$ & Recruiting & $\begin{array}{l}\text { NCT } \\
003437759\end{array}$ \\
\hline $\begin{array}{l}\text { Effect of UMSCs derived exosomes on dry eye in } \\
\text { patients with cGVHD }\end{array}$ & $\begin{array}{l}\text { Dry eye symptoms } \\
\text { in patients with } \\
\text { chronic GVH }\end{array}$ & $\begin{array}{l}\text { Artificial tears applicate for } 2 \text { weeks followed by UMSC- } \\
\text { exosomes ( } 10 \mu \mathrm{g} / \text { drop four times a day for } 14 \text { days) }\end{array}$ & $\begin{array}{l}\text { Phase } \\
|/| \mid\end{array}$ & Recruiting & $\begin{array}{l}\text { NCT } \\
04213248\end{array}$ \\
\hline $\begin{array}{l}\text { Exosome of mesenchymal stem cells for multiple } \\
\text { organ dysfunction syndrome after surgical repair of } \\
\text { acute type A aortic dissection }\end{array}$ & $\begin{array}{l}\text { Multiple organ } \\
\text { dysfunction } \\
\text { syndrome (MODS) }\end{array}$ & $\begin{array}{l}\text { Intravenous infusions of MSC-EVs ( } 150 \text { mg once a day for } \\
14 \text { days) }\end{array}$ & N/A & $\begin{array}{l}\text { Not-yet } \\
\text { recruiting }\end{array}$ & $\begin{array}{l}\text { NCT } \\
04356300\end{array}$ \\
\hline $\begin{array}{l}\text { Effect of microvesicles (MVs) and exosomes } \\
\text { therapy on } \beta \text {-cell mass in type I Diabetes Mellitus }\end{array}$ & $\begin{array}{l}\text { Diabetes mellitus } \\
\text { Type } 1\end{array}$ & $\begin{array}{l}\text { Two intravenous infusions of UC-MSC -MVs. The first } \\
\text { close of UC-MSC-exosomes in a dose sups from } 1.2 \text { to } \\
1.5 \times 10^{6} / \text { UC-MSC/kg, the second dose after } 7 \text { days of } \\
\text { UC-MSC-vesicles in a dose of sups from } 1.2 \text { to } 1.5 \times 10^{6} \\
\text { UC-MSCs } / \mathrm{kg}\end{array}$ & $\begin{array}{l}\text { Phase } \\
\|/ /\|\end{array}$ & Unknown & $\begin{array}{l}\text { NCT } \\
02138331\end{array}$ \\
\hline $\begin{array}{l}\text { iExosomes in treating participants with metastatic } \\
\text { pancreas cancer with KrasG12D mutation }\end{array}$ & $\begin{array}{l}\text { Metastatic } \\
\text { pancreatic ductal } \\
\text { adenocarcinoma } \\
\text { harboring Kras } \\
\text { G12D mutations }\end{array}$ & $\begin{array}{l}\text { Intravenous injection of MSC-exosomes with KRASG 12D } \\
\text { siRNA over } 15-20 \text { min on days: } 1,4 \text {, and } 10 \text {. Treatment } \\
\text { repeats every } 14 \text { days for up to } 3 \text { courses }\end{array}$ & $\mathrm{N} / \mathrm{A}$ & $\begin{array}{l}\text { Not-yet } \\
\text { recruiting }\end{array}$ & $\begin{array}{l}\text { NCT } \\
03608631\end{array}$ \\
\hline
\end{tabular}

*Information obtained from https://clinicaltrials.gov on $2^{\text {nd }}$ December 2020.

application of MSCs into patients with severe COVID-19 (215). It spurred numerous clinical trials across the globe (216) and recommendations for their compassionate use (217). The safety and encouraging tolerance of MSCs by COVID-19 patients was shown afterward (218). The randomized clinical trial performed in Nanjing, China demonstrated positive effects of the intravenous administration of human umbilical cord blood MSCs in patients with severe COVID-19 (219).

It has also been proposed that many therapeutic activities of MSCs are executed through extracellular vesicles (EVs) released by them (105). Therefore, it was anticipated the anti-COVID-19 action of EVs $(220,221)$. A case series of 24 patients revealed no adverse effects and suggested the possibility for blood oxygenation restoration, cytokine storm downregulation, and immunity reconstitution after intravenous infusion of EVs (222).

In summary, MSCs and EVs derived from them might be an attractive option for treating severe and critically ill COVID-19 patients. This therapeutic strategy exploits the immunomodulatory and antifibrotic characteristics of MSCs and their derivatives. There are reported highly promising early phase clinical trials with these 
investigational products; though large, randomized, and doubleblinded clinical trials are still needed for an approval by regulatory bodies and their widespread application.

\section{CONCLUDING REMARKS AND FUTURE PERSPECTIVES}

A growing body of evidence supports the notion that MSCderived EVs have similar immunomodulatory properties as their parental cells. Administration of MSC-EVs in different experimental settings and clinical trials of various diseases, in particular those with an inflammatory component, promote tissue regeneration and healing after the injury, while attenuating inflammation. Alternative therapeutic strategies involving EVs avoid risks associated with the use of stem or genetically modified cells. Moreover, replacing cell transplantation with the use of EVs isolated from them can simplify the application and reduce the risk of micro embolism during systemic cell infusion. However, there is still a discrepancy between the different isolation protocols as a result of which is obtained the various subsets of EVs, non-vesicular particles and protein aggregates' contamination. It is also a big challenge to obtain a large-scale EVs' production (223).

\section{REFERENCES}

1. Friedenstein AJ, Chailakhjan RK, Lalykina KS. The development of fibroblast colonies in monolayer cultures of guinea-pig bone marrow and spleen cells. Cell Tissue Kinet (1970) 3(4):393-403. doi: 10.1111/j.13652184.1970.tb00347.x

2. Friedenstein AJ, Chailakhyan RK, Gerasimov UV. Bone marrow osteogenic stem cells: in vitro cultivation and transplantation in diffusion chambers. Cell Tissue Kinet (1987) 20(3):263-72. doi: 10.1111/j.1365-2184.1987.tb01309.x

3. Friedenstein AJ, Chailakhyan RK, Latsinik NV, Panasyuk AF, Keiliss-Borok IV. Stromal cells responsible for transferring the microenvironment of the hemopoietic tissues. Cloning in vitro and retransplantation in vivo. Transplantation (1974) 17(4):331-40. doi: 10.1097/00007890-19740400000001

4. Caplan AI. Mesenchymal stem cells. J Orthop Res Off Publ Orthop Res Soc (1991) 9(5):641-50. doi: 10.1002/jor.1100090504

5. Caplan AI. Mesenchymal Stem Cells: Time to Change the Name! Stem Cells Transl Med (2017) 6(6):1445-51. doi: 10.1002/sctm.17-0051

6. Gardner OFW, Alini M, Stoddart MJ. Mesenchymal Stem Cells Derived from Human Bone Marrow. Methods Mol Biol Clifton NJ (2015) 1340:4152. doi: 10.1007/978-1-4939-2938-2_3

7. Penfornis P, Pochampally R. Isolation and expansion of mesenchymal stem cells/multipotential stromal cells from human bone marrow. Methods $\mathrm{Mol}$ Biol Clifton NJ (2011) 698:11-21. doi: 10.1007/978-1-60761-999-4_2

8. Pittenger MF, Mackay AM, Beck SC, Jaiswal RK, Douglas R, Mosca JD, et al. Multilineage potential of adult human mesenchymal stem cells. Science (1999) 284(5411):143-7. doi: 10.1126/science.284.5411.143

9. Lee OK, Kuo TK, Chen W-M, Lee K-D, Hsieh S-L, Chen T-H. Isolation of multipotent mesenchymal stem cells from umbilical cord blood. Blood (2004) 103(5):1669-75. doi: 10.1182/blood-2003-05-1670

10. Vasaghi A, Dehghani A, Khademalhosseini Z, Khosravi Maharlooei M, Monabati A, Attar A. Parameters that influence the isolation of multipotent mesenchymal stromal cells from human umbilical cord blood. Hematol Oncol Stem Cell Ther (2013) 6(1):1-8. doi: 10.1016/j.hemonc.2013.02.002
Moreover, a choice of an appropriate strategy to isolate wellpurified EVs is crucial to remain EVs-related functions and achieve the desired therapeutic effect (224). Therefore, there is a pivotal need to find a consensus on gold-standard method in order to MSC-EVs application in clinical studies. Thus, MSCEVs offer promising novel therapeutics, however standardization and production of EVs need to be established before they are approved for routine use in the clinic.

\section{AUTHOR CONTRIBUTIONS}

$\mathrm{SD}, \mathrm{MJ}$, and BL invented the initial conception of the paper. SD and $\mathrm{BL}$ wrote the manuscript. AA designed the figures. $\mathrm{SD}, \mathrm{AA}$, MJ, BL edited the manuscript and approved the final version of the manuscript. All authors contributed to the article and approved the submitted version.

\section{FUNDING}

This work was supported by NCR\&D grant EXPLORE ME within the "STRATEGMED I" program. SD was supported by START 2020 scholarship sponsored by The Foundation for Polish Science.

11. Qiao C, Xu W, Zhu W, Hu J, Qian H, Yin Q, et al. Human mesenchymal stem cells isolated from the umbilical cord. Cell Biol Int (2008) 32(1):8-15. doi: 10.1016/j.cellbi.2007.08.002

12. Wang H-S, Hung S-C, Peng S-T, Huang C-C, Wei H-M, Guo Y-J, et al. Mesenchymal stem cells in the Wharton's jelly of the human umbilical cord. Stem Cells Dayt Ohio (2004) 22(7):1330-7. doi: 10.1634/stemcells.2004-0013

13. Pelekanos RA, Sardesai VS, Futrega K, Lott WB, Kuhn M, Doran MR. Isolation and Expansion of Mesenchymal Stem/Stromal Cells Derived from Human Placenta Tissue. J Vis Exp JoVE (2016) 112:54204. doi: 10.3791/54204

14. Semenov OV, Koestenbauer S, Riegel M, Zech N, Zimmermann R, Zisch AH, et al. Multipotent mesenchymal stem cells from human placenta: critical parameters for isolation and maintenance of stemness after isolation. Am J Obstet Gynecol (2010) 202(2):193.e1-193.e13. doi: 10.1016/j.ajog.2009.10.869

15. Murphy SV, Atala A. Amniotic fluid and placental membranes: unexpected sources of highly multipotent cells. Semin Reprod Med (2013) 31(1):62-8. doi: 10.1055/s-0032-1331799

16. Bunnell BA, Flaat M, Gagliardi C, Patel B, Ripoll C. Adipose-derived stem cells: isolation, expansion and differentiation. Methods San Diego Calif (2008) 45(2):115-20. doi: 10.1016/j.ymeth.2008.03.006

17. Mahmoudifar N, Doran PM. Mesenchymal Stem Cells Derived from Human Adipose Tissue. Methods Mol Biol Clifton NJ (2015) 1340:53-64 doi: 10.1007/978-1-4939-2938-2_4

18. Li Q, Sun W, Wang X, Zhang K, Xi W, Gao P. Skin-Derived Mesenchymal Stem Cells Alleviate Atherosclerosis via Modulating Macrophage Function. Stem Cells Transl Med (2015) 4(11):1294-301. doi: 10.5966/sctm.2015-0020

19. Bernal A, Fernández M, Pérez LM, San Martín N, Gálvez BG. Method for obtaining committed adult mesenchymal precursors from skin and lung tissue. PloS One (2012) 7(12):e53215. doi: 10.1371/journal.pone.0053215

20. Wang Y, Yu X, Chen E, Li L. Liver-derived human mesenchymal stem cells: a novel therapeutic source for liver diseases. Stem Cell Res Ther (2016) 7(1):71. doi: 10.1186/s13287-016-0330-3

21. Huang GT-J, Gronthos S, Shi S. Mesenchymal stem cells derived from dental tissues vs. those from other sources: their biology and role in regenerative medicine. J Dent Res (2009) 88(9):792-806. doi: 10.1177/0022034509340867 
22. Gargett CE, Schwab KE, Zillwood RM, Nguyen HPT, Wu D. Isolation and culture of epithelial progenitors and mesenchymal stem cells from human endometrium. Biol Reprod (2009) 80(6):1136-45. doi: 10.1095/ biolreprod.108.075226

23. Jazedje T, Perin PM, Czeresnia CE, Maluf M, Halpern S, Secco M, et al. Human fallopian tube: a new source of multipotent adult mesenchymal stem cells discarded in surgical procedures. J Transl Med (2009) 7:46. doi: 10.1186/1479-5876-7-46

24. Cheng M-T, Yang H-W, Chen T-H, Lee OK-S. Isolation and characterization of multipotent stem cells from human cruciate ligaments. Cell Prolif (2009) 42(4):448-60. doi: 10.1111/j.1365-2184.2009.00611.x

25. Dominici M, Le Blanc K, Mueller I, Slaper-Cortenbach I, Marini F, Krause $\mathrm{D}$, et al. Minimal criteria for defining multipotent mesenchymal stromal cells. The International Society for Cellular Therapy position statement. Cytotherapy (2006) 8(4):315-7. doi: 10.1080/14653240600855905

26. Colter DC, Sekiya I, Prockop DJ. Identification of a subpopulation of rapidly self-renewing and multipotential adult stem cells in colonies of human marrow stromal cells. Proc Natl Acad Sci U S A (2001) 98(14):7841-5. doi: 10.1073/pnas.141221698

27. Bobis S, Jarocha D, Majka M. Mesenchymal stem cells: characteristics and clinical applications. Folia Histochem Cytobiol (2006) 44(4):215-30.

28. Wagner $\mathrm{W}, \mathrm{Ho} \mathrm{AD}$. Mesenchymal stem cell preparations-comparing apples and oranges. Stem Cell Rev (2007) 3(4):239-48. doi: 10.1007/s12015-0079001-1

29. Gregory CA, Singh H, Perry AS, Prockop DJ. The Wnt signaling inhibitor dickkopf-1 is required for reentry into the cell cycle of human adult stem cells from bone marrow. J Biol Chem (2003) 278(30):28067-78. doi: 10.1074/ jbc.M300373200

30. Schofield R. The relationship between the spleen colony-forming cell and the haemopoietic stem cell. Blood Cells (1978) 4(1-2):7-25.

31. Van Camp JK, Beckers S, Zegers D, Van Hul W. Wnt signaling and the control of human stem cell fate. Stem Cell Rev Rep (2014) 10(2):207-29. doi: 10.1007/s12015-013-9486-8

32. Lv F-J, Tuan RS, Cheung KMC, Leung VYL. Concise review: the surface markers and identity of human mesenchymal stem cells. Stem Cells Dayt Ohio (2014) 32(6):1408-19. doi: 10.1002/stem.1681

33. Brooke G, Tong H, Levesque J-P, Atkinson K. Molecular trafficking mechanisms of multipotent mesenchymal stem cells derived from human bone marrow and placenta. Stem Cells Dev (2008) 17(5):929-40. doi: $10.1089 / \mathrm{scd} .2007 .0156$

34. Honczarenko M, Le Y, Swierkowski M, Ghiran I, Glodek AM, Silberstein LE. Human bone marrow stromal cells express a distinct set of biologically functional chemokine receptors. Stem Cells Dayt Ohio (2006) 24(4):1030-41. doi: 10.1634/stemcells.2005-0319

35. Nauta AJ, Fibbe WE. Immunomodulatory properties of mesenchymal stromal cells. Blood (2007) 110(10):3499-506. doi: 10.1182/blood-2007-02069716

36. Koç ON, Day J, Nieder M, Gerson SL, Lazarus HM, Krivit W. Allogeneic mesenchymal stem cell infusion for treatment of metachromatic leukodystrophy (MLD) and Hurler syndrome (MPS-IH). Bone Marrow Transpl (2002) 30(4):215-22. doi: 10.1038/sj.bmt.1703650

37. Chan JL, Tang KC, Patel AP, Bonilla LM, Pierobon N, Ponzio NM, et al. Antigen-presenting property of mesenchymal stem cells occurs during a narrow window at low levels of interferon-gamma. Blood (2006) 107 (12):4817-24. doi: 10.1182/blood-2006-01-0057

38. Eliopoulos N, Stagg J, Lejeune L, Pommey S, Galipeau J. Allogeneic marrow stromal cells are immune rejected by MHC class I- and class II-mismatched recipient mice. Blood (2005) 106(13):4057-65. doi: 10.1182/blood-2005-031004

39. Ding D-C, Shyu W-C, Lin S-Z. Mesenchymal stem cells. Cell Transpl (2011) 20(1):5-14. doi: 10.3727/096368910X

40. English K. Mechanisms of mesenchymal stromal cell immunomodulation. Immunol Cell Biol (2013) 91(1):19-26. doi: 10.1038/icb.2012.56

41. Sohni A, Verfaillie CM. Mesenchymal stem cells migration homing and tracking. Stem Cells Int (2013) 2013:130763. doi: 10.1155/2013/130763

42. Alimperti S, You H, George T, Agarwal SK, Andreadis ST. Cadherin-11 regulates both mesenchymal stem cell differentiation into smooth muscle cells and the development of contractile function in vivo. J Cell Sci (2014) 127(Pt 12):2627-38. doi: 10.1242/jcs.134833

43. Xu W, Zhang X, Qian H, Zhu W, Sun X, Hu J, et al. Mesenchymal stem cells from adult human bone marrow differentiate into a cardiomyocyte phenotype in vitro. Exp Biol Med Maywood NJ (2004) 229(7):623-31. doi: $10.1177 / 153537020422900706$

44. Lee K-D, Kuo TK-C, Whang-Peng J, Chung Y-F, Lin C-T, Chou S-H, et al. In vitro hepatic differentiation of human mesenchymal stem cells. Hepatol Baltim Md (2004) 40(6):1275-84. doi: 10.1002/hep.20469

45. Stock P, Brückner S, Winkler S, Dollinger MM, Christ B. Human bone marrow mesenchymal stem cell-derived hepatocytes improve the mouse liver after acute acetaminophen intoxication by preventing progress of injury. Int J Mol Sci (2014) 15(4):7004-28. doi: 10.3390/ijms15047004

46. Bai C, Gao Y, Li Q, Feng Y, Yu Y, Meng G, et al. Differentiation of chicken umbilical cord mesenchymal stem cells into beta-like pancreatic islet cells. Artif Cells Nanomed Biotechnol (2015) 43(2):106-11. doi: 10.3109/ 21691401.2013.864662

47. Guan M, Xu Y, Wang W, Lin S. Differentiation into neurons of rat bone marrow-derived mesenchymal stem cells. Eur Cytokine Netw (2014) 25 (3):58-63. doi: 10.1684/ecn.2014.0357

48. Spees JL, Lee RH, Gregory CA. Mechanisms of mesenchymal stem/stromal cell function. Stem Cell Res Ther (2016) 317(1):125. doi: 10.1186/s13287016-0363-7

49. Dabrowska S, Sypecka J, Jablonska A, Strojek L, Wielgos M, DomanskaJanik K, et al. Neuroprotective Potential and Paracrine Activity of Stromal Vs. Culture-Expanded hMSC Derived from Wharton Jelly under CoCultured with Hippocampal Organotypic Slices. Mol Neurobiol (2018) 55 (7):6021-36. doi: 10.1007/s12035-017-0802-1

50. Kim DH, Yoo KH, Choi KS, Choi J, Choi S-Y, Yang S-E, et al. Gene expression profile of cytokine and growth factor during differentiation of bone marrow-derived mesenchymal stem cell. Cytokine (2005) 31(2):11926. doi: 10.1016/j.cyto.2005.04.004

51. Liu R, Yang Y, Yan X, Zhang K. Abnormalities in cytokine secretion from mesenchymal stem cells in psoriatic skin lesions. Eur J Dermatol EJD (2013) 23(5):600-7. doi: 10.1684/ejd.2013.2149

52. Zimmerlin L, Park TS, Zambidis ET, Donnenberg VS, Donnenberg AD. Mesenchymal stem cell secretome and regenerative therapy after cancer. Biochimie (2013) 95(12):2235-45. doi: 10.1016/j.biochi.2013.05.010

53. Spees JL, Olson SD, Whitney MJ, Prockop DJ. Mitochondrial transfer between cells can rescue aerobic respiration. Proc Natl Acad Sci U S A (2006) 103(5):1283-8. doi: 10.1073/pnas.0510511103

54. Charbord P. Bone marrow mesenchymal stem cells: historical overview and concepts. Hum Gene Ther (2010) 21(9):1045-56. doi: 10.1089/hum.2010.115

55. Diaz-Solano D, Wittig O, Ayala-Grosso C, Pieruzzini R, Cardier JE. Human olfactory mucosa multipotent mesenchymal stromal cells promote survival, proliferation, and differentiation of human hematopoietic cells. Stem Cells Dev (2012) 21(17):3187-96. doi: 10.1089/scd.2012.0084

56. Anthony BA, Link DC. Regulation of hematopoietic stem cells by bone marrow stromal cells. Trends Immunol (2014) 35(1):32-7. doi: 10.1016/ j.it.2013.10.002

57. Muguruma $\mathrm{Y}$, Yahata $\mathrm{T}$, Miyatake $\mathrm{H}$, Sato $\mathrm{T}$, Uno $\mathrm{T}$, Itoh $\mathrm{J}$, et al. Reconstitution of the functional human hematopoietic microenvironment derived from human mesenchymal stem cells in the murine bone marrow compartment. Blood (2006) 107(5):1878-87. doi: 10.1182/blood-2005-062211

58. Bronckaers A, Hilkens P, Martens W, Gervois P, Ratajczak J, Struys T, et al. Mesenchymal stem/stromal cells as a pharmacological and therapeutic approach to accelerate angiogenesis. Pharmacol Ther (2014) 143(2):18196. doi: $10.1016 /$ j.pharmthera.2014.02.013

59. Hung S-C, Pochampally RR, Chen S-C, Hsu S-C, Prockop DJ. Angiogenic effects of human multipotent stromal cell conditioned medium activate the PI3K-Akt pathway in hypoxic endothelial cells to inhibit apoptosis, increase survival, and stimulate angiogenesis. Stem Cells Dayt Ohio (2007) 25 (9):2363-70. doi: 10.1634/stemcells.2006-0686

60. Kinnaird T, Stabile E, Burnett MS, Lee CW, Barr S, Fuchs S, et al. Marrowderived stromal cells express genes encoding a broad spectrum of arteriogenic cytokines and promote in vitro and in vivo arteriogenesis 
through paracrine mechanisms. Circ Res (2004) 94(5):678-85. doi: 10.1161/ 01.RES.0000118601.37875.AC

61. Wu Y, Chen L, Scott PG, Tredget EE. Mesenchymal stem cells enhance wound healing through differentiation and angiogenesis. Stem Cells Dayt Ohio (2007) 25(10):2648-59. doi: 10.1634/stemcells.2007-0226

62. Mead B, Logan A, Berry M, Leadbeater W, Scheven BA. Paracrine-mediated neuroprotection and neuritogenesis of axotomised retinal ganglion cells by human dental pulp stem cells: comparison with human bone marrow and adipose-derived mesenchymal stem cells. PloS One (2014) 9(10):e109305. doi: 10.1371/journal.pone.0109305

63. Johnson TV, DeKorver NW, Levasseur VA, Osborne A, Tassoni A, Lorber B, et al. Identification of retinal ganglion cell neuroprotection conferred by platelet-derived growth factor through analysis of the mesenchymal stem cell secretome. Brain J Neurol (2014) 137(Pt 2):503-19. doi: 10.1093/brain/ awt 292

64. Preda MB, Rønningen T, Burlacu A, Simionescu M, Moskaug JØ, Valen G. Remote transplantation of mesenchymal stem cells protects the heart against ischemia-reperfusion injury. Stem Cells Dayt Ohio (2014) 32(8):2123-34. doi: $10.1002 /$ stem. 1687

65. Zhao J-J, Liu J-L, Liu L, Jia H-Y. Protection of mesenchymal stem cells on acute kidney injury. Mol Med Rep (2014) 9(1):91-6. doi: 10.3892/ mmr.2013.1792

66. Karaoz E, Genç ZS, Demircan PÇ, Aksoy A, Duruksu G. Protection of rat pancreatic islet function and viability by coculture with rat bone marrowderived mesenchymal stem cells. Cell Death Dis (2010) 1:e36. doi: 10.1038/ cddis. 2010.14

67. Ullah I, Subbarao RB, Rho GJ. Human mesenchymal stem cells - current trends and future prospective. Biosci Rep (2015) 35(2):e00191. doi: 10.1042/ BSR20150025

68. Rosen ED, MacDougald OA. Adipocyte differentiation from the inside out. Nat Rev Mol Cell Biol (2006) 7(12):885-96. doi: 10.1038/nrm2066

69. Zhu H, Yang A, Du J, Li D, Liu M, Ding F, et al. Basic fibroblast growth factor is a key factor that induces bone marrow mesenchymal stem cells towards cells with Schwann cell phenotype. Neurosci Lett (2014) 559:82-7. doi: 10.1016/j.neulet.2013.11.044

70. Tu Z, Li Q, Bu H, Lin F. Mesenchymal stem cells inhibit complement activation by secreting factor H. Stem Cells Dev (2010) 19(11):1803-9. doi: $10.1089 / \mathrm{scd} .2009 .0418$

71. Schraufstatter IU, Discipio RG, Zhao M, Khaldoyanidi SK. C3a and C5a are chemotactic factors for human mesenchymal stem cells, which cause prolonged ERK1/2 phosphorylation. J Immunol Baltim Md 1950 (2009) 182(6):3827-36. doi: 10.4049/jimmunol.0803055

72. Moll G, Jitschin R, von Bahr L, Rasmusson-Duprez I, Sundberg B, Lönnies L, et al. Mesenchymal stromal cells engage complement and complement receptor bearing innate effector cells to modulate immune responses. PloS One (2011) 6(7):e21703. doi: 10.1371/journal.pone.0021703

73. Chen L, Tredget EE, Wu PYG, Wu Y. Paracrine Factors of Mesenchymal Stem Cells Recruit Macrophages and Endothelial Lineage Cells and Enhance Wound Healing. PloS One (2008) 3(4):e1886. doi: 10.1371/journal.pone.0001886

74. François M, Romieu-Mourez R, Li M, Galipeau J. Human MSC suppression correlates with cytokine induction of indoleamine 2,3-dioxygenase and bystander M2 macrophage differentiation. Mol Ther J Am Soc Gene Ther (2012) 20(1):187-95. doi: 10.1038/mt.2011.189

75. Maggini J, Mirkin G, Bognanni I, Holmberg J, Piazzón IM, Nepomnaschy I, et al. Mouse bone marrow-derived mesenchymal stromal cells turn activated macrophages into a regulatory-like profile. PloS One (2010) 5(2):e9252. doi: 10.1371/journal.pone.0009252

76. Monguió-Tortajada M, Roura S, Gálvez-Montón C, Franquesa M, BayesGenis A, Borràs FE. Mesenchymal Stem Cells Induce Expression of CD73 in Human Monocytes In Vitro and in a Swine Model of Myocardial Infarction In Vivo. Front Immunol (2017) 8:1577. doi: 10.3389/fimmu.2017.01577

77. Giunti D, Parodi B, Usai C, Vergani L, Casazza S, Bruzzone S, et al. Mesenchymal stem cells shape microglia effector functions through the release of CX3CL1. Stem Cells Dayt Ohio (2012) 30(9):2044-53. doi: 10.1002/stem.1174

78. van den Akker F, de Jager SCA, Sluijter JPG. Mesenchymal stem cell therapy for cardiac inflammation: immunomodulatory properties and the influence of toll-like receptors. Mediators Inflamm (2013) 2013:181020. doi: 10.1155/ 2013/181020

79. Raffaghello L, Bianchi G, Bertolotto M, Montecucco F, Busca A, Dallegri F, et al. Human mesenchymal stem cells inhibit neutrophil apoptosis: a model for neutrophil preservation in the bone marrow niche. Stem Cells Dayt Ohio (2008) 26(1):151-62. doi: 10.1634/stemcells.2007-0416

80. Quinn K, Henriques M, Parker T, Slutsky AS, Zhang H. Human neutrophil peptides: a novel potential mediator of inflammatory cardiovascular diseases. Am J Physiol Heart Circ Physiol (2008) 295(5):H1817-1824. doi: 10.1152/ajpheart.00472.2008

81. Kim H-S, Yun J-W, Shin T-H, Lee S-H, Lee B-C, Yu K-R, et al. Human umbilical cord blood mesenchymal stem cell-derived PGE2 and TGF- $\beta 1$ alleviate atopic dermatitis by reducing mast cell degranulation. Stem Cells Dayt Ohio (2015) 33(4):1254-66. doi: 10.1002/stem.1913

82. Brown JM, Nemeth K, Kushnir-Sukhov NM, Metcalfe DD, Mezey E. Bone marrow stromal cells inhibit mast cell function via a COX2-dependent mechanism. Clin Exp Allergy J Br Soc Allergy Clin Immunol (2011) 41 (4):526-34. doi: 10.1111/j.1365-2222.2010.03685.x

83. Nemeth K, Wilson T, Rada B, Parmelee A, Mayer B, Buzas E, et al. Characterization and function of histamine receptors in human bone marrow stromal cells. Stem Cells Dayt Ohio (2012) 30(2):222-31. doi: $10.1002 /$ stem.771

84. Spaggiari GM, Capobianco A, Abdelrazik H, Becchetti F, Mingari MC, Moretta L. Mesenchymal stem cells inhibit natural killer-cell proliferation, cytotoxicity, and cytokine production: role of indoleamine 2,3-dioxygenase and prostaglandin E2. Blood (2008) 111(3):1327-33. doi: 10.1182/blood2007-02-074997

85. Zhao Z-G, Cao Z, Xu W, Sun L, You Y, Li F, et al. Immune protection function of multipotent mesenchymal stromal cells: role of transforming growth factor- $\beta 1$. Cancer Invest (2012) 30(9):646-56. doi: 10.3109/ 07357907.2012.721038

86. Spaggiari GM, Capobianco A, Becchetti S, Mingari MC, Moretta L. Mesenchymal stem cell-natural killer cell interactions: evidence that activated NK cells are capable of killing MSCs, whereas MSCs can inhibit IL-2-induced NK-cell proliferation. Blood (2006) 107(4):1484-90. doi: 10.1182/blood-2005-07-2775

87. Djouad F, Charbonnier L-M, Bouffi C, Louis-Plence P, Bony C, Apparailly F, et al. Mesenchymal stem cells inhibit the differentiation of dendritic cells through an interleukin-6-dependent mechanism. Stem Cells Dayt Ohio (2007) 25(8):2025-32. doi: 10.1634/stemcells.2006-0548

88. Li Y-P, Paczesny S, Lauret E, Poirault S, Bordigoni P, Mekhloufi F, et al. Human mesenchymal stem cells license adult CD34+ hemopoietic progenitor cells to differentiate into regulatory dendritic cells through activation of the Notch pathway. J Immunol Baltim Md 1950 (2008) 180 (3):1598-608. doi: 10.4049/jimmunol.180.3.1598

89. Su W-R, Zhang Q-Z, Shi S-H, Nguyen AL, Le AD. Human gingiva-derived mesenchymal stromal cells attenuate contact hypersensitivity via prostaglandin E2-dependent mechanisms. Stem Cells Dayt Ohio (2011) 29 (11):1849-60. doi: 10.1002/stem.738

90. Liu X, Qu X, Chen Y, Liao L, Cheng K, Shao C, et al. Mesenchymal stem/ stromal cells induce the generation of novel IL-10-dependent regulatory dendritic cells by SOCS3 activation. J Immunol Baltim Md 1950 (2012) 189 (3):1182-92. doi: 10.4049/jimmunol.1102996

91. Zhang B, Liu R, Shi D, Liu X, Chen Y, Dou X, et al. Mesenchymal stem cells induce mature dendritic cells into a novel Jagged-2-dependent regulatory dendritic cell population. Blood (2009) 113(1):46-57. doi: 10.1182/blood2008-04-154138

92. Chiesa S, Morbelli S, Morando S, Massollo M, Marini C, Bertoni A, et al. Mesenchymal stem cells impair in vivo T-cell priming by dendritic cells. Proc Natl Acad Sci U S A (2011) 108(42):17384-9. doi: 10.1073/pnas.1103650108

93. Bai L, Lennon DP, Eaton V, Maier K, Caplan AI, Miller SD, et al. Human bone marrow-derived mesenchymal stem cells induce Th2-polarized immune response and promote endogenous repair in animal models of multiple sclerosis. Glia (2009) 57(11):1192-203. doi: 10.1002/glia.20841

94. Batten P, Sarathchandra P, Antoniw JW, Tay SS, Lowdell MW, Taylor PM, et al. Human mesenchymal stem cells induce $\mathrm{T}$ cell anergy and downregulate $\mathrm{T}$ cell allo-responses via the TH2 pathway: relevance to tissue engineering 
human heart valves. Tissue Eng (2006) 12(8):2263-73. doi: 10.1089/ ten.2006.12.2263

95. Goodwin M, Sueblinvong V, Eisenhauer P, Ziats NP, LeClair L, Poynter ME, et al. Bone marrow-derived mesenchymal stromal cells inhibit Th2mediated allergic airways inflammation in mice. Stem Cells Dayt Ohio (2011) 29(7):1137-48. doi: 10.1002/stem.656

96. Ghannam S, Pène J, Moquet-Torcy G, Torcy-Moquet G, Jorgensen C, Yssel H. Mesenchymal stem cells inhibit human Th17 cell differentiation and function and induce a T regulatory cell phenotype. J Immunol Baltim $\mathrm{Md}$ 1950 (2010) 185(1):302-12. doi: 10.4049/jimmunol.0902007

97. Kong Q-F, Sun B, Bai S-S, Zhai D-X, Wang G-Y, Liu Y-M, et al. Administration of bone marrow stromal cells ameliorates experimental autoimmune myasthenia gravis by altering the balance of Th1/Th2/Th17/ Treg cell subsets through the secretion of TGF-beta. J Neuroimmunol (2009) 207(1-2):83-91. doi: 10.1016/j.jneuroim.2008.12.005

98. Rasmusson I, Ringdén O, Sundberg B, Le Blanc K. Mesenchymal stem cells inhibit the formation of cytotoxic $\mathrm{T}$ lymphocytes, but not activated cytotoxic T lymphocytes or natural killer cells. Transplantation (2003) 76(8):1208-13. doi: 10.1097/01.TP.0000082540.43730.80

99. English K, Ryan JM, Tobin L, Murphy MJ, Barry FP, Mahon BP. Cell contact, prostaglandin $\mathrm{E}(2)$ and transforming growth factor beta 1 play nonredundant roles in human mesenchymal stem cell induction of CD4+CD25 (High) forkhead box P3+ regulatory T cells. Clin Exp Immunol (2009) 156 (1):149-60. doi: 10.1111/j.1365-2249.2009.03874.x

100. Wang Y, Zhang A, Ye Z, Xie H, Zheng S. Bone marrow-derived mesenchymal stem cells inhibit acute rejection of rat liver allografts in association with regulatory T-cell expansion. Transplant Proc (2009) 41 (10):4352-6. doi: 10.1016/j.transproceed.2009.08.072

101. Corcione A, Benvenuto F, Ferretti E, Giunti D, Cappiello V, Cazzanti F, et al. Human mesenchymal stem cells modulate B-cell functions. Blood (2006) 107 (1):367-72. doi: 10.1182/blood-2005-07-2657

102. Augello A, Tasso R, Negrini SM, Amateis A, Indiveri F, Cancedda R, et al. Bone marrow mesenchymal progenitor cells inhibit lymphocyte proliferation by activation of the programmed death 1 pathway. Eur J Immunol (2005) 35 (5):1482-90. doi: 10.1002/eji.200425405

103. Traggiai E, Volpi S, Schena F, Gattorno M, Ferlito F, Moretta L, et al. Bone marrow-derived mesenchymal stem cells induce both polyclonal expansion and differentiation of $\mathrm{B}$ cells isolated from healthy donors and systemic lupus erythematosus patients. Stem Cells Dayt Ohio (2008) 26(2):562-9. doi: 10.1634/stemcells.2007-0528

104. Mellman I, Emr SD. A Nobel Prize for membrane traffic: vesicles find their journey's end. J Cell Biol (2013) 203(4):559-61. doi: 10.1083/jcb.201310134

105. Koniusz S, Andrzejewska A, Muraca M, Srivastava AK, Janowski M, Lukomska B. Extracellular Vesicles in Physiology, Pathology, and Therapy of the Immune and Central Nervous System, with Focus on Extracellular Vesicles Derived from Mesenchymal Stem Cells as Therapeutic Tools. Front Cell Neurosci (2016) 10:109. doi: 10.3389/fncel.2016.00109

106. Lai CP-K, Breakefield XO. Role of exosomes/microvesicles in the nervous system and use in emerging therapies. Front Physiol (2012) 3:228. doi: 10.3389/fphys.2012.00228

107. Biancone L, Bruno S, Deregibus MC, Tetta C, Camussi G. Therapeutic potential of mesenchymal stem cell-derived microvesicles. Nephrol Dial Transplant Off Publ Eur Dial Transpl Assoc Eur Ren Assoc (2012) 27 (8):3037-42. doi: 10.1093/ndt/gfs168

108. Frühbeis C, Fröhlich D, Kuo WP, Krämer-Albers E-M. Extracellular vesicles as mediators of neuron-glia communication. Front Cell Neurosci (2013) 7:182. doi: $10.3389 /$ fncel.2013.00182

109. Sabin K, Kikyo N. Microvesicles as mediators of tissue regeneration. Transl Res J Lab Clin Med (2014) 163(4):286-95. doi: 10.1016/j.trsl.2013.10.005

110. Mathivanan S, Ji H, Simpson RJ. Exosomes: extracellular organelles important in intercellular communication. J Proteomics (2010) 73 (10):1907-20. doi: 10.1016/j.jprot.2010.06.006

111. Subra C, Laulagnier K, Perret B, Record M. Exosome lipidomics unravels lipid sorting at the level of multivesicular bodies. Biochimie (2007) 89 (2):205-12. doi: 10.1016/j.biochi.2006.10.014

112. Turturici G, Tinnirello R, Sconzo G, Geraci F. Extracellular membrane vesicles as a mechanism of cell-to-cell communication: advantages and disadvantages. Am J Physiol Cell Physiol (2014) 306(7):C621-633. doi: 10.1152/ajpcell.00228.2013

113. György B, Szabó TG, Pásztói M, Pál Z, Misják P, Aradi B, et al. Membrane vesicles, current state-of-the-art: emerging role of extracellular vesicles. Cell Mol Life Sci CMLS (2011) 68(16):2667-88. doi: 10.1007/s00018-011-0689-3

114. Lavoie JR, Rosu-Myles M. Uncovering the secretes of mesenchymal stem cells. Biochimie (2013) 95(12):2212-21. doi: 10.1016/j.biochi.2013.06.017

115. Skalnikova H, Motlik J, Gadher SJ, Kovarova H. Mapping of the secretome of primary isolates of mammalian cells, stem cells and derived cell lines. Proteomics (2011) 11(4):691-708. doi: 10.1002/pmic.201000402

116. Kim H-S, Choi D-Y, Yun SJ, Choi S-M, Kang JW, Jung JW, et al. Proteomic analysis of microvesicles derived from human mesenchymal stem cells. J Proteome Res (2012) 11(2):839-49. doi: 10.1021/pr200682z

117. Kowal J, Tkach M, Théry C. Biogenesis and secretion of exosomes. Curr Opin Cell Biol (2014) 29:116-25. doi: 10.1016/j.ceb.2014.05.004

118. Urbanelli L, Buratta S, Sagini K, Ferrara G, Lanni M, Emiliani C. Exosomebased strategies for Diagnosis and Therapy. Recent Patents CNS Drug Discovery (2015) 10(1):10-27. doi: 10.2174/1574889810666150702124059

119. Subra C, Grand D, Laulagnier K, Stella A, Lambeau G, Paillasse M, et al. Exosomes account for vesicle-mediated transcellular transport of activatable phospholipases and prostaglandins. J Lipid Res (2010) 51(8):2105-20. doi: 10.1194/jlr.M003657

120. Rani S, O’Brien K, Kelleher FC, Corcoran C, Germano S, Radomski MW, et al. Isolation of exosomes for subsequent mRNA, MicroRNA, and protein profiling. Methods Mol Biol Clifton NJ (2011) 784:181-95. doi: 10.1007/9781-61779-289-2_13

121. Jenjaroenpun P, Kremenska Y, Nair VM, Kremenskoy M, Joseph B, Kurochkin IV. Characterization of RNA in exosomes secreted by human breast cancer cell lines using next-generation sequencing. PeerJ (2013) 1: e201. doi: $10.7717 /$ peerj.201

122. Ogawa Y, Taketomi Y, Murakami M, Tsujimoto M, Yanoshita R. Small RNA transcriptomes of two types of exosomes in human whole saliva determined by next generation sequencing. Biol Pharm Bull (2013) 36(1):66-75. doi: 10.1248/bpb.b12-00607

123. Toh WS, Lai RC, Zhang B, Lim SK. MSC exosome works through a proteinbased mechanism of action. Biochem Soc Trans (2018) 2046(4):843-53. doi: 10.1042/BST20180079

124. Liang X, Zhang L, Wang S, Han Q, Zhao RC. Exosomes secreted by mesenchymal stem cells promote endothelial cell angiogenesis by transferring miR-125a. J Cell Sci (2016) 01129(11):2182-9. doi: 10.1242/ jcs. 170373

125. Gong M, Yu B, Wang J, Wang Y, Liu M, Paul C, et al. Mesenchymal stem cells release exosomes that transfer miRNAs to endothelial cells and promote angiogenesis. Oncotarget (2017) 8(28):45200-12. doi: 10.18632/ oncotarget. 16778

126. Pakravan K, Babashah S, Sadeghizadeh M, Mowla SJ, MossahebiMohammadi M, Ataei F, et al. MicroRNA-100 shuttled by mesenchymal stem cell-derived exosomes suppresses in vitro angiogenesis through modulating the mTOR/HIF-1 $\alpha /$ VEGF signaling axis in breast cancer cells. Cell Oncol Dordr (2017) 40(5):457-70. doi: 10.1007/s13402-017-0335-7

127. Li X, Liu L, Yang J, Yu Y, Chai J, Wang L, et al. Exosome Derived From Human Umbilical Cord Mesenchymal Stem Cell Mediates MiR-181c Attenuating Burn-induced Excessive Inflammation. EBioMedicine (2016) 8:72-82. doi: 10.1016/j.ebiom.2016.04.030

128. Song Y, Dou H, Li X, Zhao X, Li Y, Liu D, et al. Exosomal miR-146a Contributes to the Enhanced Therapeutic Efficacy of Interleukin-1ß-Primed Mesenchymal Stem Cells Against Sepsis. Stem Cells Dayt Ohio (2017) 35 (5):1208-21. doi: 10.1002/stem.2564

129. Wang X, Gu H, Qin D, Yang L, Huang W, Essandoh K, et al. Exosomal miR223 Contributes to Mesenchymal Stem Cell-Elicited Cardioprotection in Polymicrobial Sepsis. Sci Rep (2015) 5:13721. doi: 10.1038/srep13721

130. Qu Y, Zhang Q, Cai X, Li F, Ma Z, Xu M, et al. Exosomes derived from miR181-5p-modified adipose-derived mesenchymal stem cells prevent liver fibrosis via autophagy activation. J Cell Mol Med (2017) 21(10):2491-502. doi: $10.1111 / \mathrm{jcmm} .13170$

131. Lou G, Yang Y, Liu F, Ye B, Chen Z, Zheng M, et al. MiR-122 modification enhances the therapeutic efficacy of adipose tissue-derived mesenchymal 
stem cells against liver fibrosis. J Cell Mol Med (2017) 21(11):2963-73. doi: $10.1111 / \mathrm{jcmm} .13208$

132. Song X-J, Zhang L, Li Q, Li Y, Ding F-H, Li X. hUCB-MSC derived exosomal miR-124 promotes rat liver regeneration after partial hepatectomy via downregulating Foxg1. Life Sci (2020) 265:118821. doi: 10.1016/ j.lfs.2020.118821

133. Budoni M, Fierabracci A, Luciano R, Petrini S, Di Ciommo V, Muraca M. The immunosuppressive effect of mesenchymal stromal cells on B lymphocytes is mediated by membrane vesicles. Cell Transpl (2013) 22 (2):369-79. doi: 10.3727/096368911X582769b

134. Mokarizadeh A, Delirezh N, Morshedi A, Mosayebi G, Farshid A-A, Mardani K. Microvesicles derived from mesenchymal stem cells: potent organelles for induction of tolerogenic signaling. Immunol Lett (2012) 147 (1-2):47-54. doi: 10.1016/j.imlet.2012.06.001

135. Garín MI, Chu C-C, Golshayan D, Cernuda-Morollón E, Wait R, Lechler RI. Galectin-1: a key effector of regulation mediated by $\mathrm{CD} 4+\mathrm{CD} 25+\mathrm{T}$ cells. Blood (2007) 109(5):2058-65. doi: 10.1182/blood-2006-04-016451

136. Blois SM, Ilarregui JM, Tometten M, Garcia M, Orsal AS, Cordo-Russo R, et al. A pivotal role for galectin-1 in fetomaternal tolerance. Nat Med (2007) 13(12):1450-7. doi: $10.1038 / \mathrm{nm} 1680$

137. Rabinovich GA, Alonso CR, Sotomayor CE, Durand S, Bocco JL, Riera CM. Molecular mechanisms implicated in galectin-1-induced apoptosis: activation of the AP-1 transcription factor and downregulation of Bcl-2. Cell Death Differ (2000) 7(8):747-53. doi: 10.1038/sj.cdd.4400708

138. Chen W, Jin W, Hardegen N, Lei K-J, Li L, Marinos N, et al. Conversion of peripheral CD4+CD25- naive $\mathrm{T}$ cells to $\mathrm{CD} 4+\mathrm{CD} 25+$ regulatory $\mathrm{T}$ cells by TGF-beta induction of transcription factor Foxp3. J Exp Med (2003) 198 (12):1875-86. doi: 10.1084/jem.20030152

139. Lai RC, Arslan F, Lee MM, Sze NSK, Choo A, Chen TS, et al. Exosome secreted by MSC reduces myocardial ischemia/reperfusion injury. Stem Cell Res (2010) 4(3):214-22. doi: 10.1016/j.scr.2009.12.003

140. Timmers L, Lim SK, Arslan F, Armstrong JS, Hoefer IE, Doevendans PA, et al. Reduction of myocardial infarct size by human mesenchymal stem cell conditioned medium. Stem Cell Res (2007) 1(2):129-37. doi: 10.1016/ j.scr.2008.02.002

141. Arslan F, Lai RC, Smeets MB, Akeroyd L, Choo A, Aguor ENE, et al. Mesenchymal stem cell-derived exosomes increase ATP levels, decrease oxidative stress and activate PI3K/Akt pathway to enhance myocardial viability and prevent adverse remodeling after myocardial ischemia/reperfusion injury. Stem Cell Res (2013) 10(3):301-12. doi: 10.1016/j.scr.2013.01.002

142. Chen L, Wang Y, Pan Y, Zhang L, Shen C, Qin G, et al. Cardiac progenitorderived exosomes protect ischemic myocardium from acute ischemia/ reperfusion injury. Biochem Biophys Res Commun (2013) 431(3):566-71. doi: 10.1016/j.bbrc.2013.01.015

143. Sun X, Shan A, Wei Z, Xu B. Intravenous mesenchymal stem cell-derived exosomes ameliorate myocardial inflammation in the dilated cardiomyopathy. Biochem Biophys Res Commun (2018) 18503(4):2611-8. doi: 10.1016/j.bbrc.2018.08.012

144. Wei Z, Qiao S, Zhao J, Liu Y, Li Q, Wei Z, et al. miRNA-181a over-expression in mesenchymal stem cell-derived exosomes influenced inflammatory response after myocardial ischemia-reperfusion injury. Life Sci (2019) 232:116632. doi: 10.1016/j.lfs.2019.116632

145. Yu B, Kim HW, Gong M, Wang J, Millard RW, Wang Y, et al. Exosomes secreted from GATA-4 overexpressing mesenchymal stem cells serve as a reservoir of anti-apoptotic microRNAs for cardioprotection. Int J Cardiol (2015) 182:349-60. doi: 10.1016/j.ijcard.2014.12.043

146. Bian S, Zhang L, Duan L, Wang X, Min Y, Yu H. Extracellular vesicles derived from human bone marrow mesenchymal stem cells promote angiogenesis in a rat myocardial infarction model. $J$ Mol Med Berl Ger (2014) 92(4):387-97. doi: 10.1007/s00109-013-1110-5

147. Ju C, Shen Y, Ma G, Liu Y, Cai J, Kim I-M, et al. Transplantation of Cardiac Mesenchymal Stem Cell-Derived Exosomes Promotes Repair in Ischemic Myocardium. J Cardiovasc Transl Res (2018) 11(5):420-8. doi: 10.1007/ s12265-018-9822-0

148. Kang K, Ma R, Cai W, Huang W, Paul C, Liang J, et al. Exosomes Secreted from CXCR4 Overexpressing Mesenchymal Stem Cells Promote Cardioprotection via Akt Signaling Pathway following Myocardial Infarction. Stem Cells Int (2015) 2015:659890. doi: 10.1155/2015/659890
149. Vrijsen KR, Maring JA, Chamuleau SAJ, Verhage V, Mol EA, Deddens JC, et al. Exosomes from Cardiomyocyte Progenitor Cells and Mesenchymal Stem Cells Stimulate Angiogenesis Via EMMPRIN. Adv Healthc Mater (2016) 5(19):2555-65. doi: 10.1002/adhm.201600308

150. Todorova D, Simoncini S, Lacroix R, Sabatier F, Dignat-George F. Extracellular Vesicles in Angiogenesis. Circ Res (2017) 120(10):1658-73. doi: 10.1161/CIRCRESAHA.117.309681

151. Anderson JD, Johansson HJ, Graham CS, Vesterlund M, Pham MT, Bramlett CS, et al. Comprehensive Proteomic Analysis of Mesenchymal Stem Cell Exosomes Reveals Modulation of Angiogenesis via Nuclear Factor-KappaB Signaling. Stem Cells Dayt Ohio (2016) 34(3):601-13. doi: 10.1002/stem.2298

152. Shabbir A, Cox A, Rodriguez-Menocal L, Salgado M, Van Badiavas E. Mesenchymal Stem Cell Exosomes Induce Proliferation and Migration of Normal and Chronic Wound Fibroblasts, and Enhance Angiogenesis In Vitro. Stem Cells Dev (2015) 24(14):1635-47. doi: 10.1089/scd.2014.0316

153. Chuang T-J, Lin K-C, Chio C-C, Wang C-C, Chang C-P, Kuo J-R. Effects of secretome obtained from normoxia-preconditioned human mesenchymal stem cells in traumatic brain injury rats. J Trauma Acute Care Surg (2012) 73 (5):1161-7. doi: 10.1097/TA.0b013e318265d128

154. Zhang Y, Chopp M, Meng Y, Katakowski M, Xin H, Mahmood A, et al. Effect of exosomes derived from multipluripotent mesenchymal stromal cells on functional recovery and neurovascular plasticity in rats after traumatic brain injury. J Neurosurg (2015) 122(4):856-67. doi: 10.3171/2014.11.JNS14770

155. Lopez-Verrilli MA, Caviedes A, Cabrera A, Sandoval S, Wyneken U, Khoury M. Mesenchymal stem cell-derived exosomes from different sources selectively promote neuritic outgrowth. Neuroscience (2016) 320:129-39. doi: 10.1016/j.neuroscience.2016.01.061

156. Xin H, Li Y, Liu Z, Wang X, Shang X, Cui Y, et al. MiR-133b promotes neural plasticity and functional recovery after treatment of stroke with multipotent mesenchymal stromal cells in rats via transfer of exosome-enriched extracellular particles. Stem Cells Dayt Ohio (2013) 31(12):2737-46. doi: 10.1002/stem.1409

157. Xin H, Li Y, Buller B, Katakowski M, Zhang Y, Wang X, et al. Exosomemediated transfer of miR-133b from multipotent mesenchymal stromal cells to neural cells contributes to neurite outgrowth. Stem Cells Dayt Ohio (2012) 30(7):1556-64. doi: 10.1002/stem.1129

158. Deng M, Xiao H, Zhang H, Peng H, Yuan H, Xu Y, et al. Mesenchymal Stem Cell-Derived Extracellular Vesicles Ameliorates Hippocampal Synaptic Impairment after Transient Global Ischemia. Front Cell Neurosci (2017) 11:205. doi: 10.3389/fncel.2017.00205

159. Kim D, Nishida H, An SY, Shetty AK, Bartosh TJ, Prockop DJ. Chromatographically isolated CD63+CD81+ extracellular vesicles from mesenchymal stromal cells rescue cognitive impairments after TBI. Proc Natl Acad Sci U S A (2016) 113(1):170-5. doi: 10.1073/pnas.1522297113

160. Zhang Y, Chopp M, Zhang ZG, Katakowski M, Xin H, Qu C, et al. Systemic administration of cell-free exosomes generated by human bone marrow derived mesenchymal stem cells cultured under $2 \mathrm{D}$ and $3 \mathrm{D}$ conditions improves functional recovery in rats after traumatic brain injury. Neurochem Int (2017) 111:69-81. doi: 10.1016/j.neuint.2016.08.003

161. Doeppner TR, Herz J, Görgens A, Schlechter J, Ludwig A-K, Radtke S, et al. Extracellular Vesicles Improve Post-Stroke Neuroregeneration and Prevent Postischemic Immunosuppression. Stem Cells Transl Med (2015) 4 (10):1131-43. doi: 10.5966/sctm.2015-0078

162. Drommelschmidt K, Serdar M, Bendix I, Herz J, Bertling F, Prager S, et al. Mesenchymal stem cell-derived extracellular vesicles ameliorate inflammation-induced preterm brain injury. Brain Behav Immun (2017) 60:220-32. doi: 10.1016/j.bbi.2016.11.011

163. Otero-Ortega L, Laso-García F, Gómez-de Frutos MDC, Rodríguez-Frutos B, Pascual-Guerra J, Fuentes B, et al. White Matter Repair After Extracellular Vesicles Administration in an Experimental Animal Model of Subcortical Stroke. Sci Rep (2017) 7:44433. doi: 10.1038/srep44433

164. Dabrowska S, Andrzejewska A, Strzemecki D, Muraca M, Janowski M, Lukomska B. Human bone marrow mesenchymal stem cell-derived extracellular vesicles attenuate neuroinflammation evoked by focal brain injury in rats. J Neuroinflam (2019) 16(1):216. doi: 10.1186/s12974-019$1602-5$

165. Ophelders DRMG, Wolfs TGAM, Jellema RK, Zwanenburg A, Andriessen P, Delhaas T, et al. Mesenchymal Stromal Cell-Derived Extracellular Vesicles 
Protect the Fetal Brain After Hypoxia-Ischemia. Stem Cells Transl Med (2016) 5(6):754-63. doi: 10.5966/sctm.2015-0197

166. Sun G, Li G, Li D, Huang W, Zhang R, Zhang H, et al. hucMSC derived exosomes promote functional recovery in spinal cord injury mice via attenuating inflammation. Mater Sci Eng C Mater Biol Appl (2018) 89:194-204. doi: 10.1016/j.msec.2018.04.006

167. Lu Y, Zhou Y, Zhang R, Wen L, Wu K, Li Y, et al. Bone Mesenchymal Stem Cell-Derived Extracellular Vesicles Promote Recovery Following Spinal Cord Injury via Improvement of the Integrity of the Blood-Spinal Cord Barrier. Front Neurosci (2019) 13:209. doi: 10.3389/fnins.2019.00209

168. Ruppert KA, Nguyen TT, Prabhakara KS, Toledano Furman NE, Srivastava AK, Harting MT, et al. Human Mesenchymal Stromal Cell-Derived Extracellular Vesicles Modify Microglial Response and Improve Clinical Outcomes in Experimental Spinal Cord Injury. Sci Rep (2018) 8(1):480. doi: 10.1038/s41598-017-18867-w

169. Haga H, Yan IK, Takahashi K, Matsuda A, Patel T. Extracellular Vesicles from Bone Marrow-Derived Mesenchymal Stem Cells Improve Survival from Lethal Hepatic Failure in Mice. Stem Cells Transl Med (2017) 6 (4):1262-72. doi: $10.1002 / \mathrm{sctm} .16-0226$

170. Damania A, Jaiman D, Teotia AK, Kumar A. Mesenchymal stromal cellderived exosome-rich fractionated secretome confers a hepatoprotective effect in liver injury. Stem Cell Res Ther (2018) 069(1):31. doi: 10.1186/ s13287-017-0752-6

171. Anger F, Camara M, Ellinger E, Germer C-T, Schlegel N, Otto C, et al. Human Mesenchymal Stromal Cell-Derived Extracellular Vesicles Improve Liver Regeneration After Ischemia Reperfusion Injury in Mice. Stem Cells Dev (2019) 28(21):1451-62. doi: 10.1089/scd.2019.0085

172. Tamura R, Uemoto S, Tabata Y. Immunosuppressive effect of mesenchymal stem cell-derived exosomes on a concanavalin A-induced liver injury model. Inflammation Regen (2016) 36:26. doi: 10.1186/s41232-016-0030-5

173. Bruno S, Grange C, Deregibus MC, Calogero RA, Saviozzi S, Collino F, et al. Mesenchymal stem cell-derived microvesicles protect against acute tubular injury. J Am Soc Nephrol JASN (2009) 20(5):1053-67. doi: 10.1681/ ASN.2008070798

174. Gatti S, Bruno S, Deregibus MC, Sordi A, Cantaluppi V, Tetta C, et al. Microvesicles derived from human adult mesenchymal stem cells protect against ischaemia-reperfusion-induced acute and chronic kidney injury. Nephrol Dial Transplant Off Publ Eur Dial Transpl Assoc Eur Ren Assoc (2011) 26(5):1474-83. doi: 10.1093/ndt/gfr015

175. Lindoso RS, Collino F, Bruno S, Araujo DS, Sant'Anna JF, Tetta C, et al. Extracellular vesicles released from mesenchymal stromal cells modulate miRNA in renal tubular cells and inhibit ATP depletion injury. Stem Cells Dev (2014) 23(15):1809-19. doi: 10.1089/scd.2013.0618

176. Zou X, Gu D, Xing X, Cheng Z, Gong D, Zhang G, et al. Human mesenchymal stromal cell-derived extracellular vesicles alleviate renal ischemic reperfusion injury and enhance angiogenesis in rats. Am J Transl Res (2016) 8(10):4289-99.

177. Wang B, Jia H, Zhang B, Wang J, Ji C, Zhu X, et al. Pre-incubation with hucMSCexosomes prevents cisplatin-induced nephrotoxicity by activating autophagy. Stem Cell Res Ther (2017) 088(1):75. doi: 10.1186/s13287-016-0463-4

178. Collino F, Bruno S, Incarnato D, Dettori D, Neri F, Provero P, et al. AKI Recovery Induced by Mesenchymal Stromal Cell-Derived Extracellular Vesicles Carrying MicroRNAs. J Am Soc Nephrol JASN (2015) 26 (10):2349-60. doi: 10.1681/ASN.2014070710

179. Eirin A, Zhu X-Y, Jonnada S, Lerman A, van Wijnen AJ, Lerman LO. Mesenchymal Stem Cell-Derived Extracellular Vesicles Improve the Renal Microvasculature in Metabolic Renovascular Disease in Swine. Cell Transpl (2018) 27(7):1080-95. doi: 10.1177/0963689718780942

180. Zou X, Zhang G, Cheng Z, Yin D, Du T, Ju G, et al. Microvesicles derived from human Wharton's Jelly mesenchymal stromal cells ameliorate renal ischemia-reperfusion injury in rats by suppressing CX3CL1. Stem Cell Res Ther (2014) 5(2):40. doi: 10.1186/scrt428

181. Tang X-D, Shi L, Monsel A, Li X-Y, Zhu H-L, Zhu Y-G, et al. Mesenchymal Stem Cell Microvesicles Attenuate Acute Lung Injury in Mice Partly Mediated by Ang-1 mRNA. Stem Cells Dayt Ohio (2017) 35(7):1849-59. doi: $10.1002 /$ stem.2619

182. Zhu Y-G, Feng X-M, Abbott J, Fang X-H, Hao Q, Monsel A, et al. Human mesenchymal stem cell microvesicles for treatment of Escherichia coli endotoxin-induced acute lung injury in mice. Stem Cells Dayt Ohio (2014) 32(1):116-25. doi: 10.1002/stem.1504

183. Khatri M, Richardson LA, Meulia T. Mesenchymal stem cell-derived extracellular vesicles attenuate influenza virus-induced acute lung injury in a pig model. Stem Cell Res Ther (2018) 299(1):17. doi: 10.1186/s13287-0180774-8

184. Mansouri N, Willis GR, Fernandez-Gonzalez A, Reis M, Nassiri S, Mitsialis $\mathrm{SA}$, et al. Mesenchymal stromal cell exosomes prevent and revert experimental pulmonary fibrosis through modulation of monocyte phenotypes. JCI Insight (2019) 4(21):e128060. doi: 10.1172/jci.insight.128060

185. Morrison TJ, Jackson MV, Cunningham EK, Kissenpfennig A, McAuley DF, O'Kane CM, et al. Mesenchymal Stromal Cells Modulate Macrophages in Clinically Relevant Lung Injury Models by Extracellular Vesicle Mitochondrial Transfer. Am J Respir Crit Care Med (2017) 196(10):127586. doi: 10.1164/rccm.201701-0170OC

186. Park J, Kim S, Lim H, Liu A, Hu S, Lee J, et al. Therapeutic effects of human mesenchymal stem cell microvesicles in an ex vivo perfused human lung injured with severe E. coli pneumonia. Thorax (2019) 74(1):43-50. doi: 10.1136/thoraxjnl-2018-211576

187. Zhang B, Wang M, Gong A, Zhang X, Wu X, Zhu Y, et al. HucMSCExosome Mediated-Wnt4 Signaling Is Required for Cutaneous Wound Healing. Stem Cells Dayt Ohio (2015) 33(7):2158-68. doi: 10.1002/stem.1771

188. Zhang B, Wu X, Zhang X, Sun Y, Yan Y, Shi H, et al. Human umbilical cord mesenchymal stem cell exosomes enhance angiogenesis through the Wnt4/ $\beta$-catenin pathway. Stem Cells Transl Med (2015) 4(5):513-22. doi: 10.5966/ sctm.2014-0267

189. Furuta T, Miyaki S, Ishitobi H, Ogura T, Kato $\mathrm{Y}$, Kamei N, et al. Mesenchymal Stem Cell-Derived Exosomes Promote Fracture Healing in a Mouse Model. Stem Cells Transl Med (2016) 5(12):1620-30. doi: 10.5966/ sctm.2015-0285

190. Zhang S, Chu WC, Lai RC, Lim SK, Hui JHP, Toh WS. Exosomes derived from human embryonic mesenchymal stem cells promote osteochondral regeneration. Osteoarthritis Cartilage (2016) 24(12):2135-40. doi: 10.1016/ j.joca.2016.06.022

191. Li W, Liu Y, Zhang P, Tang Y, Zhou M, Jiang W, et al. Tissue-Engineered Bone Immobilized with Human Adipose Stem Cells-Derived Exosomes Promotes Bone Regeneration. ACS Appl Mater. Interfaces (2018) 10 (6):5240-54. doi: 10.1021/acsami.7b17620

192. Qin Y, Wang L, Gao Z, Chen G, Zhang C. Bone marrow stromal/stem cellderived extracellular vesicles regulate osteoblast activity and differentiation in vitro and promote bone regeneration in vivo. Sci Rep (2016) 6:21961. doi: $10.1038 /$ srep21961

193. Yang J, Liu X-X, Fan H, Tang Q, Shou Z-X, Zuo D-M, et al. Extracellular Vesicles Derived from Bone Marrow Mesenchymal Stem Cells Protect against Experimental Colitis via Attenuating Colon Inflammation, Oxidative Stress and Apoptosis. PloS One (2015) 10(10):e0140551. doi: 10.1371/journal.pone.0140551

194. Mao F, Wu Y, Tang X, Kang J, Zhang B, Yan Y, et al. Exosomes Derived from Human Umbilical Cord Mesenchymal Stem Cells Relieve Inflammatory Bowel Disease in Mice. BioMed Res Int (2017) 2017:5356760. doi: 10.1155/ 2017/5356760

195. Chang C-L, Sung P-H, Chen K-H, Shao P-L, Yang C-C, Cheng B-C, et al. Adipose-derived mesenchymal stem cell-derived exosomes alleviate overwhelming systemic inflammatory reaction and organ damage and improve outcome in rat sepsis syndrome. Am J Transl Res (2018) 10 (4):1053-70.

196. Lai P, Chen X, Guo L, Wang Y, Liu X, Liu Y, et al. A potent immunomodulatory role of exosomes derived from mesenchymal stromal cells in preventing cGVHD. J Hematol Oncol J Hematol Oncol (2018) 0711 (1):135. doi: 10.1186/s13045-018-0680-7

197. Wang L, Gu Z, Zhao X, Yang N, Wang F, Deng A, et al. Extracellular Vesicles Released from Human Umbilical Cord-Derived Mesenchymal Stromal Cells Prevent Life-Threatening Acute Graft-Versus-Host Disease in a Mouse Model of Allogeneic Hematopoietic Stem Cell Transplantation. Stem Cells Dev (2016) 25(24):1874-83. doi: 10.1089/scd.2016.0107

198. Bai L, Shao H, Wang H, Zhang Z, Su C, Dong L, et al. Effects of Mesenchymal Stem Cell-Derived Exosomes on Experimental Autoimmune Uveitis. Sci Rep (2017) 7(1):4323. doi: 10.1038/s41598-017-04559-y 
199. Nojehdehi S, Soudi S, Hesampour A, Rasouli S, Soleimani M, Hashemi SM. Immunomodulatory effects of mesenchymal stem cell-derived exosomes on experimental type-1 autoimmune diabetes. J Cell Biochem (2018) 119 (11):9433-43. doi: $10.1002 / j c b .27260$

200. Mendt M, Rezvani K, Shpall E. Mesenchymal stem cell-derived exosomes for clinical use. Bone Marrow Transpl (2019) 54(Suppl 2):789-92. doi: 10.1038/ s41409-019-0616-z

201. Jafarinia M, Alsahebfosoul F, Salehi H, Eskandari N, Ganjalikhani-Hakemi M. Mesenchymal Stem Cell-Derived Extracellular Vesicles: A Novel Cell-Free Therapy. Immunol Investigations Immunol Invest (2020) 49(7):758-80. doi: 10.1080/08820139.2020.1712416

202. Kordelas L, Rebmann V, Ludwig A-K, Radtke S, Ruesing J, Doeppner TR, et al. MSC-derived exosomes: a novel tool to treat therapy-refractory graftversus-host disease. Leukemia (2014) 28(4):970-3. doi: 10.1038/leu.2014.41

203. Katagiri W, Osugi M, Kawai T, Hibi H. First-in-human study and clinical case reports of the alveolar bone regeneration with the secretome from human mesenchymal stem cells. Head Face Med (2016) 12:5. doi: 10.1186/ s13005-016-0101-5

204. Nassar W, El-Ansary M, Sabry D, Mostafa MA, Fayad T, Kotb E, et al. Umbilical cord mesenchymal stem cells derived extracellular vesicles can safely ameliorate the progression of chronic kidney diseases. Biomater Res (2016) 20:21. doi: 10.1186/s40824-016-0068-0

205. Drela K, Stanaszek L, Nowakowski A, Kuczynska Z, Lukomska B. Experimental Strategies of Mesenchymal Stem Cell Propagation: Adverse Events and Potential Risk of Functional Changes. Stem Cells Int (2019) 2019:7012692. doi: 10.1155/2019/7012692

206. Lukomska B, Stanaszek L, Zuba-Surma E, Legosz P, Sarzynska S, Drela K. Challenges and Controversies in Human Mesenchymal Stem Cell Therapy. Stem Cells Int (2019) 2019:9628536. doi: 10.1155/2019/9628536

207. Ludwig S, Zarbock A. Coronaviruses and SARS-CoV-2: A Brief Overview. Anesth Analg (2020) 131(1):93-6. doi: 10.1213/ANE.0000000000004845

208. Arshad Ali S, Baloch M, Ahmed N, Arshad Ali A, Iqbal A. The outbreak of Coronavirus Disease 2019 (COVID-19)-An emerging global health threat. J Infect Public Health (2020) 13(4):644-6. doi: 10.1016/j.jiph.2020.02.033

209. Hu B, Huang S, Yin L. The cytokine storm and COVID-19. J Med Virol (2020) 10.1002/jmv.26232. doi: 10.1002/jmv.26232

210. George PM, Wells AU, Jenkins RG. Pulmonary fibrosis and COVID-19: the potential role for antifibrotic therapy. Lancet Respir Med (2020) 8(8):807-15. doi: 10.1016/S2213-2600(20)30225-3

211. Horie S, Masterson C, Brady J, Loftus P, Horan E, O’Flynn L, et al. Umbilical cord-derived CD362+ mesenchymal stromal cells for E. coli pneumonia: impact of dose regimen, passage, cryopreservation, and antibiotic therapy. Stem Cell Res Ther (2020) 11(1):116. doi: 10.1186/s13287-020-01624-8

212. Horák J, Nalos L, Martínková V, Beneš J, Štengl M, Matějovič M. Mesenchymal Stem Cells in Sepsis and Associated Organ Dysfunction: A Promising Future or Blind Alley? Stem Cells Int (2017) 2017:7304121. doi: 10.1155/2017/7304121

213. Chuang H-M, Shih TE, Lu K-Y, Tsai S-F, Harn H-J, Ho L-I. Mesenchymal Stem Cell Therapy of Pulmonary Fibrosis: Improvement with Target Combination. Cell Transpl (2018) 27(11):1581-7. doi: 10.1177/ 0963689718787501

214. McIntyre LA, Stewart DJ, Mei SHJ, Courtman D, Watpool I, Granton J, et al. Cellular Immunotherapy for Septic Shock. A Phase I Clinical Trial. Am J
Respir Crit Care Med (2018) 197(3):337-47. doi: 10.1164/rccm.2017051006OC

215. Lalu MM, Sullivan KJ, Mei SH, Moher D, Straus A, Fergusson DA, et al. Evaluating mesenchymal stem cell therapy for sepsis with preclinical metaanalyses prior to initiating a first-in-human trial. eLife (2016) 17:5. doi: 10.7554/eLife. 17850

216. Golchin A, Seyedjafari E, Ardeshirylajimi A. Mesenchymal Stem Cell Therapy for COVID-19: Present or Future. Stem Cell Rev Rep (2020) 16 (3):427-33. doi: 10.1007/s12015-020-09973-w

217. Atluri S, Manchikanti L, Hirsch JA. Expanded Umbilical Cord Mesenchymal Stem Cells (UC-MSCs) as a Therapeutic Strategy in Managing Critically Ill COVID-19 Patients: The Case for Compassionate Use. Pain Physician (2020) 23(2):E71-83.

218. Meng F, Xu R, Wang S, Xu Z, Zhang C, Li Y, et al. Human umbilical cordderived mesenchymal stem cell therapy in patients with COVID-19: a phase 1 clinical trial. Signal Transd Target Ther (2020) 275(1):172. doi: 10.1038/ s41392-020-00286-5

219. Shu L, Niu C, Li R, Huang T, Wang Y, Huang M, et al. Treatment of severe COVID-19 with human umbilical cord mesenchymal stem cells. Stem Cell Res Ther (2020) 1811(1):361. doi: 10.1186/s13287-020-01875-5

220. Chrzanowski W, Kim SY, McClements L. Can Stem Cells Beat COVID-19: Advancing Stem Cells and Extracellular Vesicles Toward Mainstream Medicine for Lung Injuries Associated With SARS-CoV-2 Infections. Front Bioeng Biotechnol (2020) 8:554. doi: 10.3389/fbioe.2020.00554

221. Muraca M, Pessina A, Pozzobon M, Dominici M, Galderisi U, Lazzari L, et al. Mesenchymal stromal cells and their secreted extracellular vesicles as therapeutic tools for COVID-19 pneumonia? J Control Release Off J Control Release Soc (2020) 10325:135-40. doi: 10.1016/j.jconrel.2020.06.036

222. Sengupta V, Sengupta S, Lazo A, Woods P, Nolan A, Bremer N. Exosomes Derived from Bone Marrow Mesenchymal Stem Cells as Treatment for Severe COVID-19. Stem Cells Dev (2020) 1529(12):747-54. doi: 10.1089/ scd. 2020.0080

223. Monguió-Tortajada M, Gálvez-Montón C, Bayes-Genis A, Roura S, Borràs FE. Extracellular vesicle isolation methods: rising impact of size-exclusion chromatography. Cell Mol Life Sci CMLS (2019) 76(12):2369-82. doi: 10.1007/s00018-019-03071-y

224. Monguió-Tortajada M, Roura S, Gálvez-Montón C, Pujal JM, Aran G, Sanjurjo L, et al. Nanosized UCMSC-derived extracellular vesicles but not conditioned medium exclusively inhibit the inflammatory response of stimulated T cells: implications for nanomedicine. Theranostics (2017) 7 (2):270-84. doi: 10.7150/thno.16154

Conflict of Interest: The authors declare that the research was conducted in the absence of any commercial or financial relationships that could be construed as a potential conflict of interest.

Copyright (c) 2021 Dabrowska, Andrzejewska, Janowski and Lukomska. This is an open-access article distributed under the terms of the Creative Commons Attribution License (CC BY). The use, distribution or reproduction in other forums is permitted, provided the original author(s) and the copyright owner(s) are credited and that the original publication in this journal is cited, in accordance with accepted academic practice. No use, distribution or reproduction is permitted which does not comply with these terms. 